\title{
Functional Design Criteria for the 242-A Evaporator and PUREX Plant Condensate Interim Retention Basin
}

C. C. Cejka

Date Published January 1990

Prepared for the U.S. Deparment of Energy Assistant Secretary for Defense Programs

$\begin{array}{ll}\text { Westinghouse } & \text { P.O. Box } 1970 \\ \text { Hanford Company } & \text { Richland. Washington } 99352\end{array}$

Hantord Operations and Engineering Contractor for the

U.S. Department of Energy under Contract DE-AC06-87AL10930 
WHC-EP- 0327

FUNCTIONAL DESIGN CRITERIA FOR THE 242-A EVAPORATOR AND

PUREX PLANT CONDENSATE INTERIM RETENTION BASIN

\author{
C. C. Cejka
}

ABSTRACT

This document contains the functional design criteria for a 25 -milliongallon retention basin and 10 million gallons of temporary storage tanks.

The basin and tanks will be used to store 242-A Evaporator process condensate, the Plutonium-Uranium Extraction (PUREX) Plant process distillate discharge stream, and the PUREX Plant ammonia scrubber distillate stream.

Completion of the project will allow both the 242-A Evaporator and the PUREX Plant to restart. 


\section{CONTENTS}

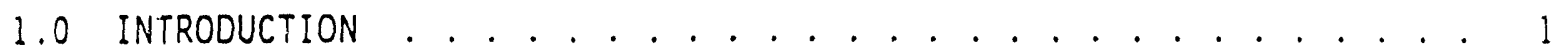

1.1 BACKGROUND ...................... 1

1.2 SCOPE . . . . . . . . . . . . . . . . . 2

2.0 FUNCTIONAL REQUIREMENTS ..................... 3

2.1 BASIN . . . . . . . . . . . . . . . 3

2.2 TEMPORARY STORAGE TANKS . . . . . . . . . . . . . . . . 4

2.3 RETENTION BASIN MONITORING WELLS. . . . . . . . . . . . . . 4

2.4 PUMPING . . . . . . . . . . . . . . . . 4

2.4.1 Leachate Collection Removal Pumps............. 4

2.4.2 Emergency Pumps . . . . . . . . . . . . . . . 5

2.5 INTENDED USEFUL LIFE....................... 5

2.6 PIPING . . . . . . . . . . . . . . . . . . . . 5

2.6.1 Leachate Fluid Return Pipes . . . . . . . . . . . . . . 5

2.6.2 Emergency Transfer Piping Systems . . . . . . . . . . . 5

$2.6 .3 \quad 242-A$ Eyaporator to the Temporary Storage Tanks
to the Basin Cells piping System

2.6.4 Piping System from the PUREX Plant to the

Temporary Storage Tanks to the Basin . . . . . . .

2.6.5 Basin to the Treatment Facility Pioing System.... . . 5

2.7 ADOITIONAL BASIN FACILITIES . . . . . . . . . . . . . . . . . 5

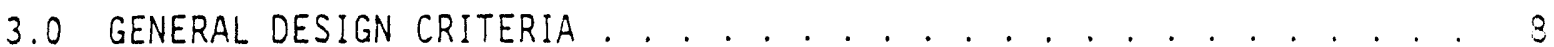

3.1 OPERATING PERSONNEL REQUIREMENTS AND FACILITIES

FOR THE BASIN

3.1.1 Utilities

3.1.2 Maintenance

3.1 .3 Security and Safeguards . . . . . . . . . . .

3.1 .4 Access .................... 10

3.1.5 Siting . . . . . . . . . . . . . . . 10

3.2 GENERAL REQUIREMENTS . . . . . . . . . . . . . . . . 10

3.2.1 Human Factors. . . . . . . . . . . . . . . . . . . . . 10

3.2.2 Natural Forces . . . . . . . . . . . . . . . . . . 11

3.2.3 Environmental Conditions . . . . . . . . . . . . . 11

3.2.4 Architectural . . . . . . . . . . . . . . . 11

4.0 QUALITY ASSURANCE REQUIREMENTS . . . . . . . . . . . . . . . . . . . . . . . 12

5.0 RISK DISCUSSION AND HAZARD CLASSIFICATION . . . . . . . . . . . . 13

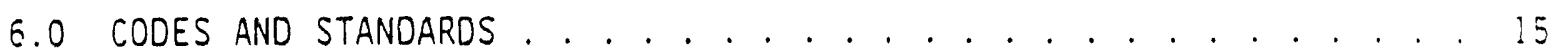

7.0 REFERENCES .......................... 18

APPENDIX A............................ . . A-I

APPENDIX B.......................... . . . . . . . 
WHC - EP-0327

\begin{abstract}
FUNCTIONAL DESIGN CRITERIA FOR THE 242-A EVAPORATOR AND PUREX PLANT CONDENSATE INTERIM RETENTION BASIN
\end{abstract}

\title{
1.0 INTRODUCTION
}

\subsection{BACXGROUND}

For the past 45 years the Hanford Site has used the favorable site characteristics of isolation, low precipitation, deep water table, and soil ion exchange properties to discharge large amounts of water containing low levels of radionuclides and stable chemicals to the soil column.

The present U.S. Department of Energy (DOE) policy requires that the use of soil columns to treat and retain suspended or dissolved radionuclides from liquid wastestreams be discontinued. This is to be implemented at the earliest date practicable in favor of wastewater treatment and waste minimization. This policy is implemented though DOE orders, which are based on federal and state environmental regulations. In 1988, the U.S. Department of Energy-Richland Operations Office (DOE-RL) issued WHC-EP-0196-1, Annual Status Report of the Plan and Schedule to Dizcontinue Disposal for Contaminated Liquids into the Soil Column at the Hanford Site--Fiscal Year 1989 (Millikin 1989).

This document coritains a strategy for implementing alternative treatment and disposal systems for aach of the wastestreams. In this strategy, the wastestreams are prioritized into two phases: Phase I and Phase II. The Phase I streams are the higher priority and will have alternative treatment and disposal systems implementeu' by June 1995. The Phase II streams will be addressed after the Phase I projects are completed.

The schedules and milestones from the projects to provide alternative treatment and disposai methods for both the Phase I and Phase II streams have been incorporated into the recently signed "Action Plan for Implementation of the Hanford Federal Facility Agreement and Consent Order, " an attachment to the Hanford Federal Facility Agreement and Consent Order (Tri-Party Agreement [TPA]) (EPA et a1. 1989).

Operation of both the 242-A Evaporator and Plutonium-Uranium Extraction (PUREX) Plant is vital to conducting the Hanford Site mission. Current mission plans cannot be supported if the 242-A Evaporator and the PURE.X Plant remain in a standby condition until currently planned treatment and disposal systems become operational. Additionally, it will not be possible to support a 11 TPA commitments if the 242-A Evaporator remains in standby condition for an extended period according to WHC-EP-0286, Double-She 71 Tank Space Analysis of Hanford Site Operating Scenarios (McKenney 1989).

The 242-A Evaporator process condensate was routed through the 207-A retention basin, where it was sampled, and then discharged to the 216-A37-1 crib. Presently, the 242-A Evaporator is on temporary standby 
WHC-EP-0327

because of a concern that past practices may have made the double-shell tank contents, and thus the 242-A Evaporator process condensat?, 1isted wastes. The PUREX Plant process distillate discharge (PDD) scream and the ammonia scrubber distillate (ASD) steam were previously being discharged to the to $216-A-45 \mathrm{crib}$ and the $216-\mathrm{A}-36 \mathrm{crib}$, respectively. In addition, an investigation of the PUREX Plant waste generation practices suggests that there is a potential for the PDD and ASD to be a listed waste.

Startup of the 200 Area Treated Effluent Disposal Facility (Project W-049H), which would treat the 242-A Evaporator and PUREX Plant effluent, is scheduled for completion in Jine of 1995.

The 242-A Evaporator and PUREX Plant must be restarted as soon as possible to complete the TPA commitments on schedule and to accomplish planned Hanford Site missions. To accomplish this, a 26-million-gallon (approximate) interim storage basin is needed to hold the condensate.

\subsection{SCOPE}

This project will provide an interim 36-million-gallon storage facility consisting of a $26-\mathrm{milli}$ ion-gallon basin capacity (13 million gallons for the 242-A Evaporator and 13 million gallons for the PUREX Plant) and 10 million gallons of temporary tank storage capacity. The two plants will send process condensate to this storage facility for approximately 15 months. The interim storage facility, for the 242-A Evaporator process condensate and PUREX Plant PDD and ASD streams will be a multicell basin design. A number of temporary tank for additional storage will also be constructed. The purpose of the temporary storage tanks will be to provide rapid online storage if the schedule or site operation dictates a need for them or when the permanent interim storage facility becomes operational. The storage facility will also provide the material and equipment to transfer the effluent from the 242-A Evaporator and from the PUREX Plant to the bas in and the temporary storage tanks, and the piping outlets for transferring the effluent from the basin to a future treatment facility. This project will construct liquid storage to permit operation of the 242-A Evaporator and the PUREX Plant until a treatment facility is operational. This facility and the necessary component.s for operating it will meet the Resource Conservation and Recovery Act (RCRA) requirements of the U.S. Environmental Protection Agency (EPA). The 242-A Evaporator process condensate will be routed through pipes directly from the evaporator to the retention basin and temporary storage tanks. Through a separate piping system, PUREX Plant PDD and ASO streams will be routed through pipes directly from the PUREX Plant to the retention basin and temporary storage tank. Design, construction, and operation will meet the requirements of the codes and standards 1 isted in Section 6.0, "Codes and standards." 


\subsection{FUNCTIONAL REQUIREMENTS}

\subsection{BASIN}

The multicell basin will be designed, constructed, and operated to meet the requirements of the Codes and Standards listed in Section 6.0 but specifically EPA/530-SW-85-014, Minimum Technology Guidance on Liner System. The active storage volume of the basin will be 26 million gallons ( 13 million gallons for $242-A$ Evaporator and 13 million galions for the PUREX Plant). The basin will be designed with sufficient volume to accommodate the active storage volume plus freeboard. Exceeding the active storage volume of the basin or mixing of the 242-A Evaporator process condensate and PUREX Plant PDD or ASD streams is not allowed.

Each storage basin cell will consist of the following:

- Cover

- Top composite liner

- Leachate collection system

- Bottom composite liner.

The slope of the side will be designed to prevent bridging and gaping and to ensure proper compaction of the composite liner soil. Manual level indicators will be installed in each cell.

The materials used for construction and operation of this storage facility will be compatible with the other materials used in the 242-A Evaporator process condensate and in the PUREX Plant PDD and ASD streains (see Appendix A). To ensure uniform strength of the liner, the material used will be of uniform thickness to $8 \%$ of the design value.

The basin cells will be filled so that there is time to test the top composite liners for leaks without interrupting the effluent flow from the 242-A Evaporator or from the PUREX Plant.

Example: A cell is filled to $25 \%$ capacity. A 1 -month waiting period then begins; during this time, the cell is examined for leaks. During the 1 -month leak detection period in the one cell, the other cell will be filled, then tested for leaks.

If a leak is found in the top composite liner, then the cell will be emptied, repaired, and tested again. capacity.

Siting of this facility will include the ability to double the storage 
Protection of the liner will be incorporated into the design to minimize damage during construction and operation. Also, penetration through the liner should be avoided.

The preferred basin is described in Appendix B.

\subsection{TEMPORARY STORAGE TANKS}

A multitank facility with 10 million gallons of active temporary storage without spare contingency capacity will be designed to the requirements of EPA 40 CFR 264 Subpart $X$. Each tank will be equipped with a cover. If a temporary storage tank must be emptied for repair or maintenance purposes then the effluent of that particular storage unit will be pumped into one of the other temporary storage tank. Mixing of the 242-A Evaporator process condensate with either the PUREX Plant PDD or ASD streams is not allowed.

The design of the temporary storage tank facility will incorporate a cover and two liners with one leachate collection system betiveen the tivo liners. The leachate collection system sump pit will be designed to contain a spill or leak in the leachate return system. Manual level indicators will be installed in each tank.

The materials used for construction and operation of this facility will be compatible with the other materials used, the 242-A Evaporator process condensate and PUREX Plant PDD and ASD streams (see Appendix A). To ensure uniform strength of the liner, the material used will be uniform within $8 \%$ of the design thickness. Protection of the liner will be incorporated into the design to minimize damage dur.ng construction and operation. Also, penetration through the liner should be avoided.

Additional temporary tank storage may be needed; therefore, the design layout will maximize the available space.

\subsection{RETENTION BASIN MONITORING WELLS}

The number, location, and type of ground-water monitoring wells for the retention basin will meet the requirements of WAC-173-303-645, WHC-173-303400 , and EPA 40 CFR Part 265.

\subsection{PUMPING}

\subsubsection{Leachate Collection Removal Pumps}

A leachate collection removal pump will be installed to.remove the fluid that accumulates in each of the leachate sumps for each of the basin cells and the temporary storage tanks. Automated switches and iristrumentation will be installed to keep fluid level in the leachate system at or below a foot of fluid head. 


\subsubsection{Emergency Pumps}

Portable or permanent pump(s) will be available to pump the contents of one basin cell or temporary storage tank to another. The pump(s) will be of sufficient size to empty a full basin cell in 7 days. The pump(s) for the temporary storage tank will be sized to empty a full temporary storage tank in I day.

\subsection{INTENDED USEFUL LIFE}

The design life of the basin and the associated piping systems will be a minimum of 30 years. The final design will take into consideration that the useful life of certain components may not be 30 years. The design 1 ife for personnel support facilities for the basin will be a minimum of 7 years. The temporary tanks and associated operation facilities will have a minimum design life of 4 years.

\subsection{PIPING}

\subsubsection{Leachate Fiuid Return Pipes}

The piping for removal of the fluid from the retention basin or temporary storage tank leachate sumps will be capable of sending fluid back to the iasin cell or temporary storage tank and matching the pump capacity. This piping system will be protected from winter freezing. Double-wall pipe and pipe fittings will be installed per WAC-173-j03. The design, construction, and material used for this piping system will protect both personnel and the environment from contamination. Sampling equipment will also be installed with the piping system to allow collection of fluid samples from the leachate collection system.

\subsubsection{Emergency Transfer Piping Systems}

The emergency transfer piping system may be either permanent or temporary and will be used for the transfer of liquid from one basin cell to another or one temporary storage tank to another. If temporary piping is used, it must be capable of being assembled and operational in 3 weeks. Pipe size will match the appropriate emergency transfer pump. Double-wall pipes and fittings with leak detection will be used per WAC-173-303. The design, construction, and materials used for this piping system will protect both personnel and the environment from contamination.

\subsubsection{2-A Evaporator to the Temporary Storage Tanks to the Basin Cells Piping System}

This piping system will run from the 242-A Evaporator to the temporary storage tanks and then to the basin. The size of the pipiny system will 
WHC -EP - 0327

allow it to handle $75 \mathrm{gal} /$ minute. Pumping needs, slope of pipe, and pipe drainage will be included in the pipe system design. The design will also include the ability to bypass the temporary storage tanks and route the 242-A Evaporator process condensate straight to the basin. The goal of not releasing radionuclides to the basin or the temporary storage tanks in excess of safety boundary limits will be realized by in-line monitoring, sampling, and shutdown of process equipment at the 242-A Evaporator. This piping system will be protected from winter freezing. Double-wall pipes and fittings with leak detection will be used per WAC-173-303. The design, construction, and materials used for this piping system will protect both personnel and the environment from contamination.

\subsubsection{Piping System from the PUREX Plant to the Temporary Storage Tanks to the Basin}

The piping system will transfer the PDD and the ASD from the PUREX Plant to the temporary storage tanks then to the basin. The piping system's size will allow it to handle a range of flow rates from 5 to $130 \mathrm{gal} / \mathrm{minute}$. Pumping needs, slope of pipe, and pipe drainage will be included in the pipe system design. The design will also include the ability to bypass the temporary storage tanks and route the PUREX Plant PDD and ASD streams straight to the basin. The goal of not releasing radionuclides to the basin or temporary storage tanks in excess of safety boundary will be realized by inline monitoring, sampling, and shut down of process equipment at the PUREX plant. This piping system will be protected from winter freezing. Doublewall pipe and fittings with leak detection will be used per WAC-173-303. The design, construction, and materials used for this piping system will protect both personnel and the environment from contamination.

\subsubsection{Basin to the Treatment Facility Piping System}

Piping fittings will be installed on the basin to allow for the future hook up of two piping system (one for the 242-A Evaporator effluent and one for PUREX Plant effluent) and sampling equipment. The fittings will be sized to transfer $130 \mathrm{gal} / \mathrm{minute}$.

\subsection{ADDITIONAL BASIN FACILITIES}

The basin operations facilities features will include the following:

- Separate changerooms for men and women (ten men and five women minimum)

- Separate change areas for street clothes and special work permit (SWP) clothes

- Portal monitor at the entrance to the SWP area 
- Separate storage for clean and dirty laundry to include laundry delivery and pickup facilities

- Personnel survey and decontamination

- Parking for ten or more vehicles

- Storage closets for supplies and a janitor's closet

- Spill kit

- Storage room for clean and contaminated equipment and supplies

- Operator space (e.g., for procedures, required records, and manuals). 
WHC - EP-0327

\subsection{GENERAL DESIGN CRITERIA}

\subsection{OPERATING PERSONNEL REQUIREMENTS AND FACILITIES FOR THE BASIN}

\subsubsection{Utilities}

The utilities for the storage basin will include the following:

- Telephone and radio communications

- Marked roadways, if interior areas are not suitable.

\subsubsection{Maintenance}

Maintenance activities for the site interior and basin areas will include the following:

- Removal of all plant growth and periodic use of herbicide to prevent new plant growth

- Application of an algicide to prevent aigae pollution

- Pest contral, especially for deer, ground squirrel, and rabbit.

The following maintenance issues will be addressed during the planning and construction phases of the site interior and basin areas.

- Sufficient room fior all equipment required for maintenance, ileaning, and equipment replacement will be provided.

- Crane access for removal and/or installation of pumps and large equipment will be provided (this includes room for support equipment such as the 80-ft-long tractor and trailer used for pumps and long equipment).

- The conceptual design will incorporate the use of interchangeable parts, access for visual inspection, and maintenance using standard tools and equipment.

Also, the maintenance personnel for the site interior and basin area will ensure that all vendors provide operating and maintenance manuals for aach new item supplied. 


\subsubsection{Security and Safeguards}

To meet security and safety guidelines, fencing around the site will include the following items.

- A 7-ft-high chainlink fence topped with three strands of barbed wire (equal to $1 \mathrm{ft}$ in height), per Hanforo Plant Standards will surround the site.

- Perimeter lighting will be added around the site as per Hanford Site Plant Standards.

- At a minimum, inside and outside roadways will be lined with either a treated biobarrier or crushed rock sprayed with herbicide: this will serve as a fire break. A 60 -ft radius will be used on a 11 roadway corners. Outside roads will have a fire break at least $20 \mathrm{ft}$ wide on either side.

- The fence will follow terrain, but sudden elevation changes will be graided out.

The placement of radio fire alarm links, smoke detectors, manual pull stations, and other safety devices will depend on the facility design.

The interior basin area safeguards include the following:

- Lighting of basin areas, if perimeter lights provides insufficient light per Occupational Safety and Health Act (OSHA) and Washington (State) Industrial Safety and Health Administration (WISHA) standards

- Fall protection around each basin cell as required by OSHA.

Facility identification and posting safeguards and security measures include the following.

- The facility will be part of the 200 East Area but outside of the limited access area (the possibility of future inclusion into the 200 East limited access area does exist); building and facility numbers for a 11 structures will reflect a 200 East Area affiliation.

- The perimeter fence will be posted as required by RCRA and Westinghouse Hanford Company manuals.

- All buildings and facilities will be provided with permanent highvisibility signs displaying the facility name and number.

- All buildings and facilities will be posted as required by RCRA and Westinghouse Hanford Company manuals. 
- Signs will be placed at facility entrances directing points-of. contact for entry. Names and numbers will be provided by Operations at a later date.

\section{1 .4 Access}

There will be a minimum of two, 24 -ft-wide large equipment access gates. One gate will serve as the main gate and the other for emergency off-normal access only. The main gate vill also have the following features.

- A radiation and hazardous waste buffer zone will exist outside the gate.

- All gates and building ton:'s will have high-integrity Corbin locks keyed to tark farm standards. The main gate and exterior personnei access doors will trigger alarms in the local control room and at 242 - A Evaporator.

- Personnel gates other than as required for interfacing with the change facilities are not required or desired.

\section{1 .5 siting}

The location of the project will be in the section of land set aside by Site Evaluation Report (SER) WHC-SD-WO49-SE-001. The exact locatinn of the this basin will be determined during the Jefinitive design phase of the project.

\subsection{GENERAL REQUIREMENTS}

\subsubsection{Human Factors}

Human factors engineering will be incorporated for safety of operations in accordance with requirements in DOE Order 6430.1A and (DOE i989). It should be noted that this facility will not normally be manned.

- Utilize to the maximum extent practical the current "Conduct of Operations" as practiced by the tank farms and described in piant operating procedures, safety analys is reports, operating specification documents, training programs, emergency and contingency plans, Westinghouse Hanford Company manuals, as-10:\%as-reasonabiy-achievable guidelines, and day-to-day operations.

- To enhance future site closure as well as ease construction costs and schedule, modular and/or prefabrication facilities can be used only if all DOE orders, federal, state, and local regulations, arid codes and standards are satisfied. Facilities will also be integrated together as much as possible to make use of common 
facilities such as office space and communications. As many structures as possible will be kept in clean areas. All access to controlled areas will be through the changeroom and main vehicle gate.

\subsubsection{Natural Forces}

The basin, temporary storage tanks, and supporting facilitites will comply with the earthquate and wind criteria defined in Hanford Plant Design SDC 4.1, Rev.11, Standard Arch-Civil Design Criteria Design Loads for Facilities.

\subsubsection{Environmental Conditions}

The 242-A Evaporator and PUREX Plant Interim Storage Basin will be exposed to the environmental conditions experienced on the 200 Area ilateau of the Hanford Site, and must therefore be designed to meet the temperature conditions described in the Hanford Plant Standard SOC-5.1, Section C, "Outdoor Design Environment," for process buildings and equipment. Operability of the 242-A Evaporator and PUREX Plant interim storage basin will not be compromised by the full range of anticipated temperature, pressure, humidity, wind, or precipitation nor will it be compromised by the periodic fluctuations of meteorological conditions typical of the Hanford Site daily or seasonal cycles.

\subsubsection{Architectural}

The structures will protect the equipment, components, and personne? from the environmental conditions anticipated for the Hanford Site. The facility will be designed to accommodate 24-hour operation and will permit continuous manned operation and surveillance in compliance with SDC 4.1 Rev.11, Standard Arch-Civil Design Criteria Design Loads for Facilities and DOE Order 6430.1A (DOE 1389). 


\subsection{QUALITY ASSURANCE REQUIREMENTS}

Quality Assurance (QA) activ'ties for all contractors involved in the design, construction, and testing of the proposed facility will be formulated and executed through the use of the Project Specific Quality Assurance Program Plan (QAPP). The QAPP will establish QA program requirements, which are used to formulate verification, inspection, and testing activities on special projects. The QA program requirements will be in accordance with DOE-RL Order 5700.1A, Quality Assurance.

The basis for establishing QA program requirements is the Impact Level and Safety Classification as defined in WHC-CM-1-3, Management Requirements and Procedures; MRP 5.43, "Impact Levels"; and MRP 5.46," Safety

Classification of Systems, Components, and Structures." The overall safety classes for the major systems, components and/or structures for projf-ts will be defined in the preliminary safety evaluation (PSE) and the preliminary safety assessment document (PSAD). 
WHC-EP-0327

\subsection{RISK DISCUSSION AND HAZARD CLASSIFICATION}

The basin design criteria as described in this document will provide an en ronmentally suitable storage method for the 242-A Evaporator and PUREX Plant effluent. The document WHC-SD-WM-PJE-004, 242-A Evaporator Interim Retention Basin Hazard Classification Analysis, states "The estimated radiological doses and toxicological exposures are well within the limits of the low hazard classification criteria. Accordingly, the facility : concluded to be a low hazard facility." This conclusion was based on discharge from the 242-A Evaporator process condensate and PUREX Plant PDD and ASD streams.

From the low hazard classification, it is anticipated that the safety classification will be three (3). Determination and justification of the actual safety classification will be in the PSE.

This project combined with other "Plan and Schedule" projects provide a reduction in chemicals and radionuclides that would be discharged to the environment. Other "Plan and Schedule" projects are providing additiona? end-of-pipe treatment and/or improved operation practices that will reduce effluent concentrations and volumes.

Risks of construction are also relatively low and will be performed in accordance with OSHA and WISHA regulations. Some work will require work near and adjacent to existing nonreactor nuclear facilities. Existing work procedures will be implemented to ensure the safety of the construction and operating personnel in the area of the existing nonreactor nuclear facilities.

The design will ensure that a single failure does not result in the loss of capability of a safety class system to accomplish its required safety functions. To protect against single failures, the design will include appropriate redundancy and will consider diversity to minimize the possibility of concurrent common-mode failures of redundant items.

Unacceptable Safety Consequences.

- Fire/Explosion.

- Criticality, at least two unlikely, independent, and concurrent changes (contingencies) in processing and/or operating conditions must happen before a criticality accident is possible. A criticality event is anticipated to be an unlikely event. This will be verified in accordarce to DOE order 6430.1A (DOE 1989). 
- Instantaneous release of radioactivity from the facility in excess of 5,00U times the Derived Concentration Guidelines (DCG) ilits at the point of discharge averaged over any 4-hour period as defined in WHC-CM-7-5. A radioactivity event is anticipated to be an unlikely event. This will be verified in accordance to DO: Order 6430.1A (DOE 1989).

- Exposure of personnel to ionizing radiation in excess of the standards and guidelines specified in the DOE Order 5480 series. 


\subsection{CODES AND STANDARDS}

The 242-A Evaporator and PUREX Plant Interim Retention Basin will be desigried to comply with RCRA containment and leak detection criteria found in 40 CFR 264 and WAC 173-303.

The following outline defines the appropriate codes, standards, regulations, guidelines and orders that also must be followed:

- DOE Order 4700.1, Project Management System

- DOE-RL Order 5440.1A, Impiementation of the National Environinentai Policy Act at the Richland Operations office

- DOF Order 5000.1, General Environmental Protection Program

- DOE-RL Order 5480.1A, Environmental Safety and Health Program for Department of Energy for Richland Operations

- DOE Order 5480.1B, Environmenta7, Safety and Health Program for Department of Energy Operations

- DOE Order 5480.4, Environmental Protection, Safety and Health Protection Standards

- DOE Order 5480.7, Fire Protection

- DOE-RL Order 5480.7A, Fire Protection

- DOE Order 5480.10, Contractor Industrial Hygiene Program

- DOE-RL Order 5480.10A, Industrial Hygiene Program

- DOE-RL Order 5480.4A, Environmental Protection, Safety, and Health Protection Standards for RL

- DOE Order 5480.1:, Radiation Protection for Occupational Workers

- DOE-RL Order 54E0.11A, Requirements for Radiation Protection

- DOE Order 5481.1B, Safety Analysis and Review System

- DOE-RL Order 5481.1, Safety Analysis and Review System

- DOE Order 5484.1, Environmental Protection Safety and Heal.th Protection Information Reporting Requirements

- DOE-RL Order 5484.1, Environmental Protection, Safety and Health Protection Information Reporting Requirements 
- DOE-RL Order 5700.1A, Qua7.ty Assurance

- DOE Order 5700.6B, Quality Assurance

- DOE Order 5820.2A, Radioactive Waste Management

- DOE-RL Order 6430.1B, Hanford Plant Standards

- DOE Order 6430.1A, General Design Criteria

- EPA/530-SW-85-014, Minimum Technology Guidance on Double Liner Systems for Landfills and Surface Impoundrients--Jesign, Construction, and Operation

- EPA/550-SW-86-031, Technica7 Guidance Document for Contractor Quality Assurance

- WAC 173-201, Water Quality Standards for Waters of the State of Washington

- Tit7e 40 CFR 260-270, Resource Conservation and Recovery ACt (RCRA), 1984

- WAC 173.216, State of Washington Waste Discharge Permit Program

- WAC 173-303, Dangerous Waste Regulation

- "Radiation Standards for Protection of the Public in the Vicinity of DOE Facilities," Memorandum from W. A. Vaughn, August 5, 1985

- WHC-CM-4-2, Quality Assurance Manual

- WHC-CM-4-3, Industrial Safety Manual

- WHC-CM-4-9, Radiological Design

- WHC-CM-4-10, Radiation Protection

- WHC-CM-4-11, ALAnA Program Manua?

- WHC-CM-4-29, Nuclear Criticality Safety Manual

- WHC-CM-4-33, Security Manual

- WHC-CM-7-5, Environmental Compliance Manual

- WHC-CM-4-46, Non Reactor Facility Safety Analysis Manual.

- WHC-CM-5-5, Operations - General Administration

- WHC-CM-5-7, Tank Farm Surveillance and Operations Administration Manual 
WHC - EP - 0327

- WHC-EP-0063, Hanford Radioactive Solid Waste Packaging Storage and Disposal Requirements

- WHC-EP-0137, Best Available Technology (economically achievable) Guidance Document for the Hanford Site

- International Nuclear Power Organization guidelines.

- National Fire Protection Association.

In addition to the above standards, applicable "National Consensus" Codes and Standards and pertirient state and local codes and standards will be used. The latest edition of all codes and standards wiil be used. 


\subsection{REFERENCES}

DOE, 1989, General Design Criteria, DOE Order 6430.1 A, U.S. Department of Energy, Washington, D.C.

EPA, DOE, and Ecology, 1989, Hanford Federal Facility Agreement and Consent Order, U.S. Environmental Protection Agency, Region 10, U.S. Department of Energy, and Washington State Department of Ecology, Richland, Washington.

McKenney, D. E., 1989, Double-Sne 77 Tank Space Analysis of Hanford Site Operating Scenarios, WHC-EP-0286, Westinghouse Hanford Company, Richland. Washington.

Millikin, E. J., 1989, Annual Status Report of the Plan and Schedule to Discontinue Disposal for Contaminated Liquids into the Soil Column at the Hanford Site--Fiscal Year 1989, WHC-EP-0196-2, Westinghouse Hanford Company, Richland, Washington. 
WHC - EP - 0327

\section{APPENDIX A}

242-A EVAPORATOR PROCESS CONDENSATE

$$
A-1 / 2
$$


The 242-A Evaporator process condensate is generated when waste from underground storage tanks is concentrated. The 102-AW tank receives dilute radioactive waste from PUREX, supernatant from PUREX decladding waste, PUREX ammonia distillate feed, and "linked" waste from several other underground storage tanks and, in turn, supplies feed to the evaporator. The decladding waste supernatant and ammonia distillate feed are processed with dilute waste in distinct evaporator campaigns. Linked campaigns are conducted that include the dilute waste and four other types of waste that are transferred to the feed tank throughout the campaign. The linked wastes include supernatant from the slurry that has been produced from previous campaigns, salt-we 11 liquor from the 200 East Area, salt-ivell liquor from the 200 West Area, and customer waste from the 100 Area. The waste stream is characterized as three discharges: the first is associated with the processing of decladding waste supernatant; the second is associated with the processing of linked feeds; and the third is associated with the processing of ammonia distillate feed. During a campaign, condensate is produced by steady-state conditions.

\section{RADIONUCLIDES}

Process Knowledge

Previously Detected: H-3, Sr-89/90, Ru-106, Sn-113, I- I29, Cs-137

Improbable: $\mathrm{Ru}-103, \mathrm{Pm}-147, \mathrm{Pu}-238, \mathrm{Pu}-239 / 240, \mathrm{Pu}-241, \mathrm{Am}-241$, Uranium

Sampled

At:

$\mathrm{RC}-3$ sampler in $242-\mathrm{A}$

Every:

Day for monthly composite-normal operations

By: Flow proportional sampler

Remark:

Analyzed

At: or by basin-high generation rates

222-S Laboratory, Westinghouse Hanford Company

\section{CHEMICALS}

Varies by: Process Configuration

Scheduled by: Random days, Process Configuration

Process Configuration(Code)

CRW Feed(APl)

Sampling Points (Code)

Sampler $R C-3$ in building 242-A(AF10)

Basin 1 of building 242-A(AP11)

Basin 2 of building 242-A(AP12)

Basin 3 of building 242-A(AP13)

Process Configuration(Code)

Linked Feed(AP2)

Sampling Points (Code)

Sampler RC-3 in building 242-A(AP20)

Basin 1 of building 242-A(AP21)

Basin 2 of building 242-A(AP22)

Basin 3 of building 242-A(AP23) 


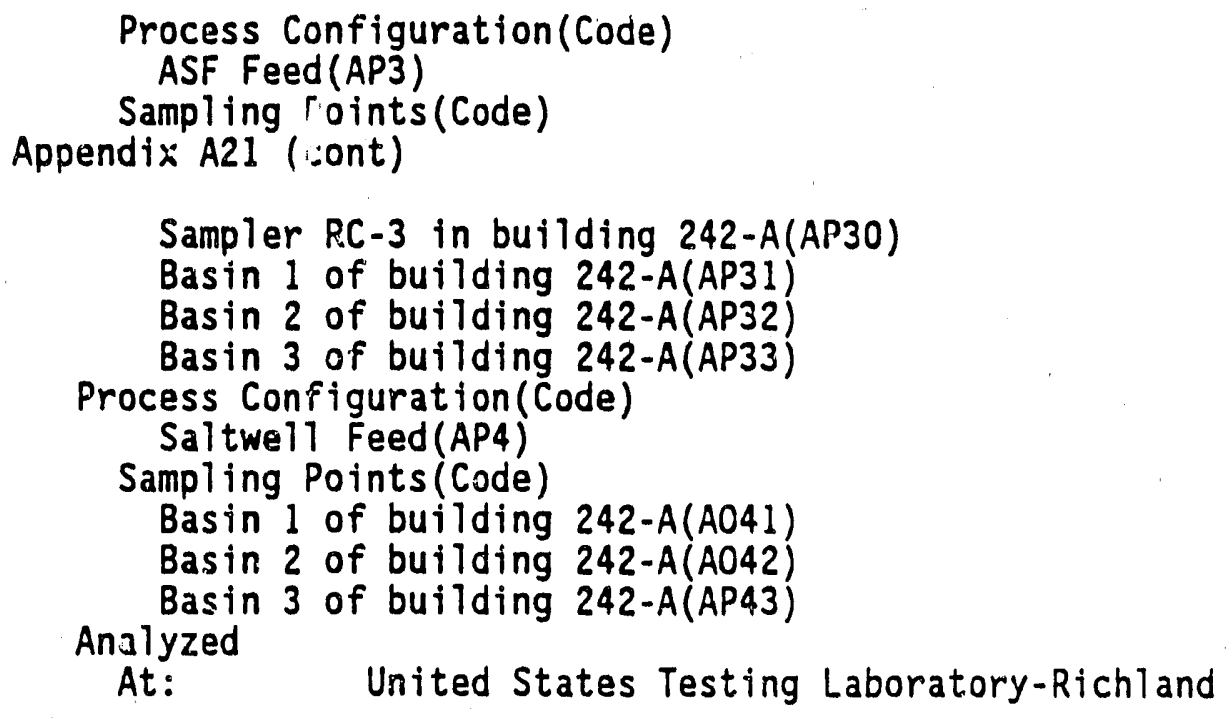


CIib Waste Management system Wastestream Activity Characteristics units in pci/L

Stream Code: AP

RADIONUCIID
ALPHA
BEIA
SR -90
RU -106
CS-137
PM-147
$U($ GROSS)
H-3
EU - 155
PU-239
SN-113

242-A Evaporacor Erocess Condensate Activity from 1977 through 1988

$\begin{array}{ll}\text { AVERAGE } & \text { MENIMTS } \\ 1.6 E+02 & 3.3 E+00 \\ 4.6 E+03 & 1.3 E+02 \\ 5.2 E+02 & 1.9 E+01 \\ 3.0 E+03 & 2.6 E+03 \\ 4.4 E+02 & 6.1 E+01 \\ 1.3 E+03 & 1.2 E+02 \\ 2.0 E+01 & 1.7 E-01 \\ 5.6 E+06 & 1.3 E+01 \\ 1.4 E+03 & 1.4 E+03 \\ 3.7 E-04 & 1.7 E-05 \\ 5.4 E+02 & 1.3 E+02\end{array}$

$\begin{array}{ll}\text { MAXIMUM } & 90 \% \text { CI IIMIT } \\ 9.5 E+02 & 3.5 E+02 \\ 7.4 E+04 & 6.0 \mathrm{E}+03 \\ 8.1 E+03 & 7.6 \mathrm{E}+02 \\ 1.2 \mathrm{E}+03 & 3.5 \mathrm{E}+03 \\ 2.6 \mathrm{E}+03 & 5.4 \mathrm{E}+02 \\ 4.1 \mathrm{E}+03 & 1.6 \mathrm{E}+03 \\ 1.4 \mathrm{E}+02 & 3.3 \mathrm{E}+01 \\ 2.4 \mathrm{E}+07 & 6.3 \mathrm{E}+06 \\ 1.4 \mathrm{E}+03 & \mathrm{~N} / \mathrm{A} \\ 2.4 \mathrm{E}-03 & 6.8 \mathrm{E}-04 \\ 2.5 \mathrm{E}+03 & 7.7 \mathrm{E}+02\end{array}$

Less-Than Data Values Have Been Omitted 
242-A Evaporator Process Condensate - CRW Feed Sample ID AP10: 2 UST Sampies

Detected Analytes

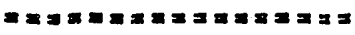

Note: Units are PPB unless otherwise indicated.

Analyte

Beta Activity (pCi/L)

Acetone (VOA)

Aluminum

Ammonium

Barium

Benzy 1 alcohol.

2-Butoxyethanol

Butoxyglycol

Butraldehyde

Butyl alcohol

\section{Calcium}

Chloride

Conductivity-Field (uS)

Mercury

Methyl n-buty I ketone

Methyl ethyl ketone

Methyl n-propyl ketone

pH-Field

Potassium

2-Propanol

Temperature-Field (celsius)

Tetraciecane

Tetrahydrofuran

TOC

Tributyl phosphate

Tridecane

Unknown

Uranium
N Average Minimum Maximum 90\% CI

$27.7 E+024.5 E .02$ 1. $1 E+031.8 E+03$

$21.8 E+031.0 E+032.6 E+034.2 E+03$

$21.3 E+03$ 1. $2 E+031.5 E+031.7 E+03$

$29.0 E+05$ 8. $2 E+05$ 1.OE+O6 1.2E+06

I $6.0 \mathrm{E}+00$

2 1. $6 \mathrm{E} \cdot C 1 \quad 1.4 \mathrm{E}+01 \quad 1.8 \mathrm{E}+012.2 \mathrm{E}+01$

2 i.. $1 E+02$ 2. $0 E+02$ 4. $3 E+02 \quad 6.7 E+02$

$23.8 E+022.3 E+025.4 E+028.6 E+02$

$11.7 \pm+01$

$25.1 E+021.0 E\{029.1 E+021.8 E+03$

$22.9 E+038.7 E+024.9 E+039.1 E+03$

$16.8 \mathrm{E}+02$

$23.9 \mathrm{E}+02 \quad 3.7 \mathrm{E}+02$ 4. $2 \mathrm{E}+02 \quad 4.8 \mathrm{E}+02$

$25.2 E-013.4 E-016.9 E-01$ 1. $1 E+00$

$16.0 E+00$

$24.8 E+013.5 E+016.2 E+019 . C E+01$

$16.0 \mathrm{E}+00$

$21.1 E+01$ 1. $1 E+01$ 1.1E+01 1.1E+01

$26.3 E+025.8 E+026.7 E+027.7 E+02$

$13.9 E+01$

$23.3 E+013.0 E+013.7 E+014.4 E+01$

$12.5 E+01$

$21.1 E+01$ 1. $1 E+01$ 1. $2 E+01$ 1.3E+OI

$23.0 E+04 \quad 1.0 E+04 \quad 4.9 E+04 \quad 8.9 E+04$

$25.8 E+022.1 E+029.5 E+021.7 E+03$

$11.4 E+01$

$23.3 E+O 1$ 2.1E+OI 4.5E+OI 7.OE+OI

3 2.OE-O1 5.8E-02 3.6E-O1 3.6E-O1 
$W H C-E P-0327$

242-A Evaporator Process Condensate - CRW Feed

Sample ID API1: 1 UST Samples

Detected Anal ptes

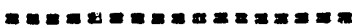

Note: Units are PFB unless otherwise indicated.

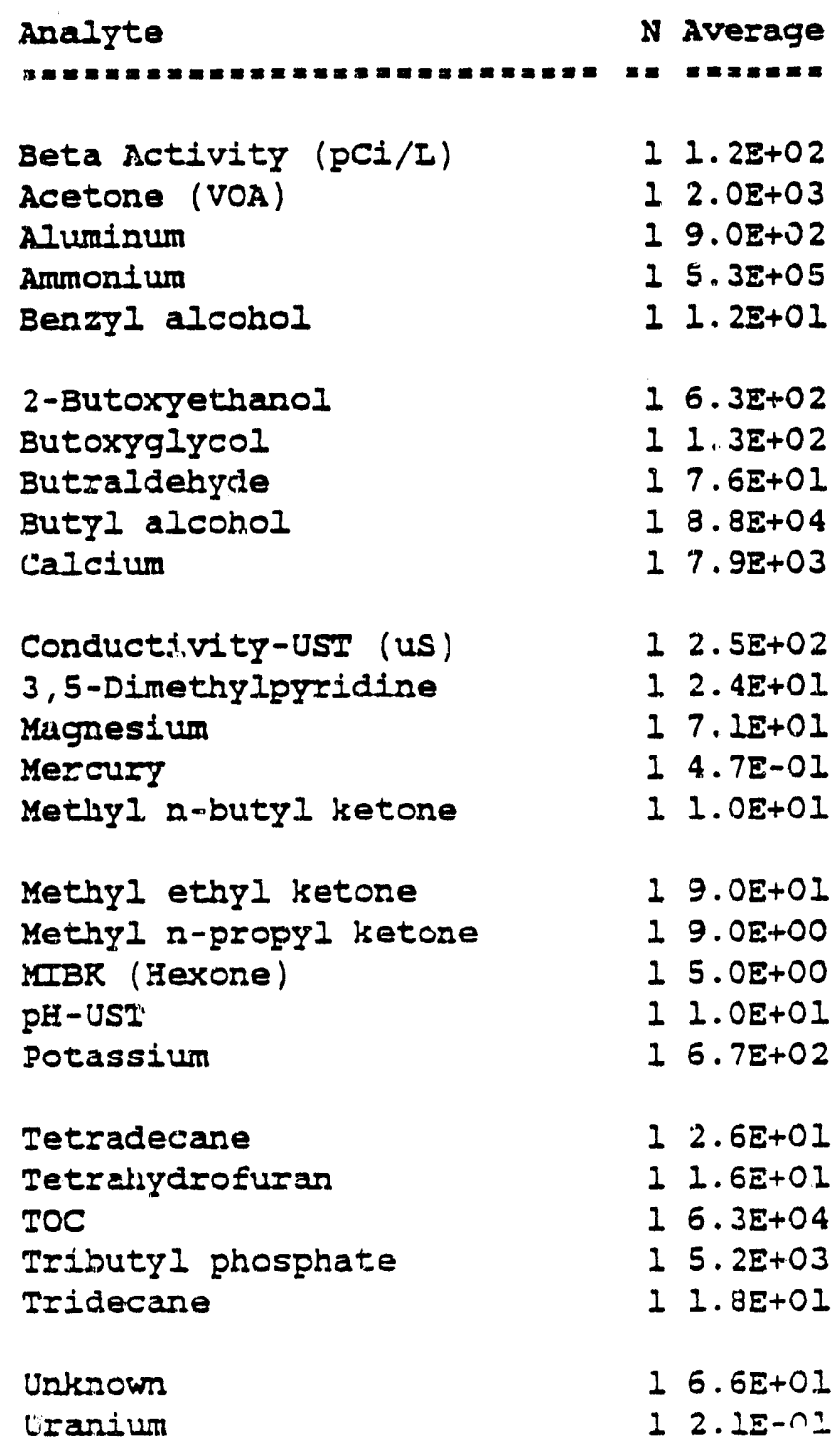


242-A Evaporator Process Condensate - CRW Feed

Sample ID AP12: 1 UST Samples

Detected Analyt:s

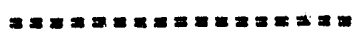

Note: Units are PPB unless otherwise indicated.

Analyte

N Average Minimum kaximum $90 \%$ CI

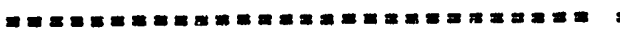

Alpha Activity (IDI, pCi/I)
Beta Activity (PCI/I)
Acetone (VOA)
Aluminum
Ammonium

2-Butoxyethanol

Butoxyglycol

Butraldehyde

Butyl alcohol

Calcium

Chloride

Conductivity-UST (uS)

3,5-Dimethylpyridine

Mercury

Methyl n-butyl ketone

Methyl ethyl ketone

Methyl n-prcpyl ketone

MIBK (Hexone)

$\mathrm{PH}-$ UST

Potassium

Tetradecane

Tetrahydrofuran

TOC

Iributy] phosphate

Tridecane

uranium
$11.5 \mathrm{E}-01$

$17.98+01$

$12.5 \mathrm{E}+03$

$11.18+03$

$14.7 \mathrm{E}+05$

$18.4 \mathrm{E}+02$

$12.3 E+02$

$15.4 E+01$

$17.8 \mathrm{E}+04$

$16.18+03$

$19.3 E+02$

$13.3 \mathrm{E}+02$

1 1. $7 \mathrm{E}+01$

1 5. $4 E-O I$

$11.12+01$

$18.8 \mathrm{E}+01$

1 $1.2 \mathrm{E}+01$

$14.0 E+00$

$11.0 E+01$

$15.9 E+02$

$11.3 E+01$

$11.8 E+01$

$15.2 E+04$

$16.8 \mathrm{E}+03$

I $9.0 \mathrm{E}+00$

2. 1. $4 E+00$ 
242-A Evaporator Process Condensate - CRW Feed Sample D API3: 1 UST Samples

Detected Analytes

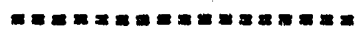

Note: Units are PPB unless otherwise indicated.

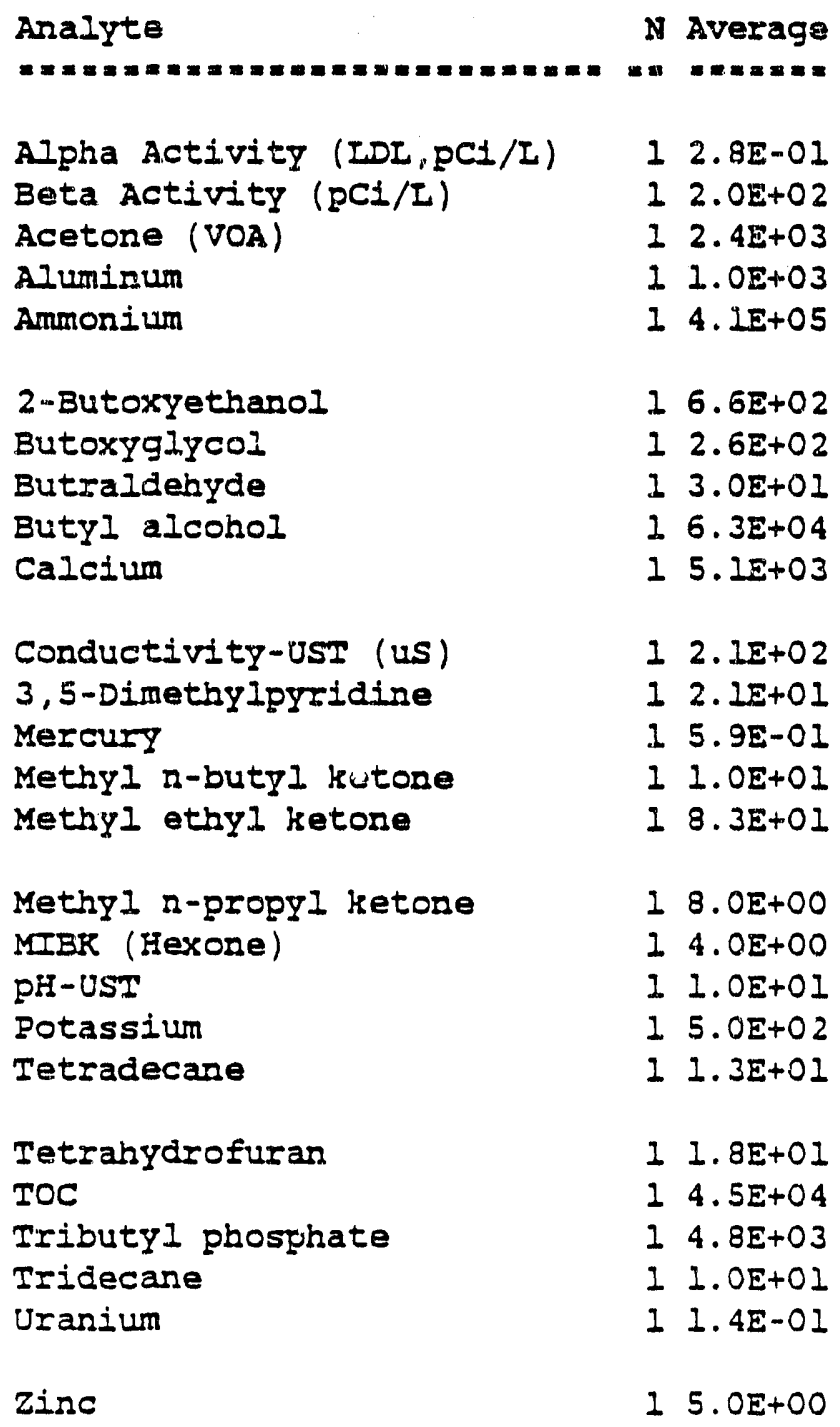


WHC -EP- 0327

\author{
242-A Evaporator Process Condensate - Ijisked Feed \\ Sample ID AP20: 7 UST Samples \\ Detected Analytes

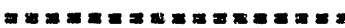

Note: Units are PPB unless otherwise indicated.

Analyto

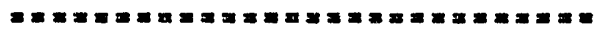

AIpha Activity (IDL, pCi/L) Beta Activity (pCi/L)

Acetone (VOA)

Alumisum

Ammonium

Barium

Benzaldehyde

Benzyl alcohol

Butoxydiglycol

2-Butoxyethasol

Butoxyglycol

Butraldehyde

Butyl alcohol

Cadmium

Calcium

Caproic acid

chloride

conductivity-gield (us)

Copper

Dimethylnitrosamine

Dodecane

Ethoxytriethylene glycol

Fluoride (ISE)

Heptadecare

Hexadecane

Iron

Magnesiun

Mercury

Methoxydiglycol

Methoxytriglycol

Methyl a-butyl ketone

Methyl ethyl ketone

Methyl n-propyl ketone

MIBK (Hexone)

Nichel
N Average Minimum Maximum 90\% CI

6.7E-01 2.4E-01 1. $6 \mathrm{E}+001.4 \mathrm{E}+00$

$62.4 E+031.2 E+024.3 E+03 \quad 3.3 E+03$

$61.4 E+03 \quad 8.0 E+015.1 E+03 \quad 2.6 E+03$

6 8. $2 \mathrm{E}+021.6 \mathrm{E}+021.6 \mathrm{E}+03$ 1. $1 \mathrm{E}+03$

7 8. $2 E+043.0 E+032.5 E+05$ 1. $4 E+05$

$16.0 E+00$

$12.3 E+01$

$11.0 \mathrm{E}+01$

$11.1 \mathrm{E}+01$

$52.9 E+022.2 E+019.0 E+02 \quad 5.4 E+02$

$18.9 \mathrm{E}+01$

$23.1 E+01$ 2.1E+OI 4.1E+OI 6.2E+O1

5 4.5E+02 1. $7 E+01$ 1. $1 E+03$ 8. $1 E+02$

1. $5.0 E+00$

$72.2 E+034.4 E+024.4 E+033.0 E+03$

$17.0 \mathrm{E}+01$

$21.1 \mathrm{E}+03 \quad 9.6 \mathrm{E}+02 \quad 1.2 \mathrm{E}+03 \quad 1.4 \mathrm{E}+03$

$72.2 E+02$ 1. $2 E+02$ 4. $7 E+02 \quad 2.8 E+02$

$43.0 E+O 1$ 1. $4 E+O 1 \quad 7.3 E+O 15.3 E+O I$

$15.7 \mathrm{E}+01$

$24.3 E+014.0 E+014.6 E+015.2 E+01$

$11.5 \mathrm{E}+02$

$13.5 \mathrm{E}+01$

$11.8 \mathrm{E}+01$

$11.7 \mathrm{E}+01$

$48.7 E+014.5 E+011.6 E+021.3 E+02$

$68.9 E+025.1 E+014.0 E+03 \quad 1.8 E+03$

$43.3 E-01$ 2.1E-OI $4.8 E-01$ 4.2E-OI

$12.8 E+01$

$13.7 \mathrm{E}+02$

$21.6 E+01$ 1.3E+OI 2.0E+OI 2.7E+OI

2 1.1E+02 9. $4 E+01$ 1. $2 E+021.5 E+02$

$21.1 E+011.1 E+011.1 E+011.1 E+01$

$23.7 E+01$ E. $0 E+006.8 E+01$ 1.3E+02

$31.5 E+01$ 1. $1 E+011.7 E+011.8 E+01$

A- 10 
242-A Evaporator Process Condensate - Iinked Feed

$$
\text { Sample ID AP20: } 7 \text { UST Samples }
$$

Detected Analytes

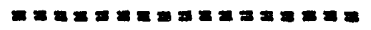

Note: Units are PPB unless otherwise indicated.

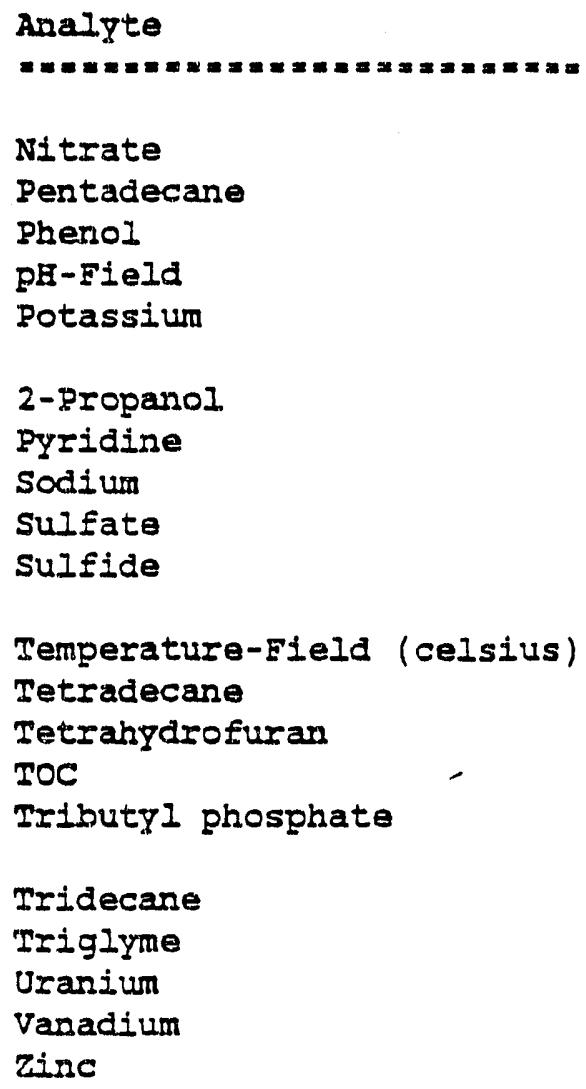

N Average Minimum Maximum 90\% CI

$42.8 E+03 \quad 7.1 E+02 \quad 5.0 E+03 \quad 4.6 E+03$

$12.0 E+01$

$13.3 E+01$

$\begin{array}{llll}7 & 9.3 E+00 \quad 7.8 E+00 \quad 1.0 E+01 & 9.9 E+00\end{array}$

$\begin{array}{lll}6.6 E+02 & 1.7 E+02 & 1.7 E+03 \quad 9.2 E+02\end{array}$

$21.6 \mathrm{E}+01 \quad 1.0 \mathrm{E}+01 \quad 2.2 \mathrm{E}+01 \quad 3.4 \mathrm{E}+01$

$15.5 \mathrm{E}+02$

$7 \quad 4.6 E+03 \quad 2.5 E+02 \quad 2.6 E+04 \quad 9.7 E+03$

$5 \quad 4.6 \mathrm{E}+03 \quad 8.1 \mathrm{E}+02$ 1.3E+04 8.1E+03

$23.5 E+04 \quad 5.2 E+03 \quad 6.6 E+04 \quad 1.3 E+05$

$\begin{array}{llllll}7 & 2.7 E+01 & 1.4 E+01 & 3.9 E+01 & 3.1 E+01\end{array}$

$42.4 E+02 \quad 7.7 E+01 \quad 4.4 E+02 \quad 3.8 E+02$

$\begin{array}{lllll}4 & 2.3 E+O 1 & 1.7 E+01 & 3.0 E+01 & 2.8 E+01\end{array}$

$\begin{array}{llllll}7 & 1.7 \mathrm{E}+04 & 1.2 \mathrm{E}+0.3 \quad 5.6 \mathrm{E}+04 & 2.8 \mathrm{E}+04\end{array}$

$\begin{array}{llllll}6 & 4.9 \mathrm{E}+03 & 6.6 \mathrm{E}+01 & 2.1 \mathrm{E}+04 & 9.7 \mathrm{E}+03\end{array}$

$42.2 \mathrm{E}+02 \quad 8.0 \mathrm{E}+01 \quad 3.5 \mathrm{E}+02 \quad 3.2 \mathrm{E}+02$

$19.0 \mathrm{E}+01$

$\begin{array}{llllll}5 & 2.5 E-01 & 2.7 E-02 & 4.7 E-01 & 3.7 E-01\end{array}$

$15.0 E+\infty 0$

5 1. $5 E+01 \quad 5.0 E+00 \quad 3.4 E+01 \quad 2.3 E+01$ 
WHC-EP- 0327

\begin{abstract}
242-A Evaporator Process Condensate - Iinked Feed
Sample ID AP21: 1 UST Samples
\end{abstract}

Detected Analytes

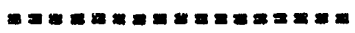

Note: Units are PPB unless otherwise indicated.

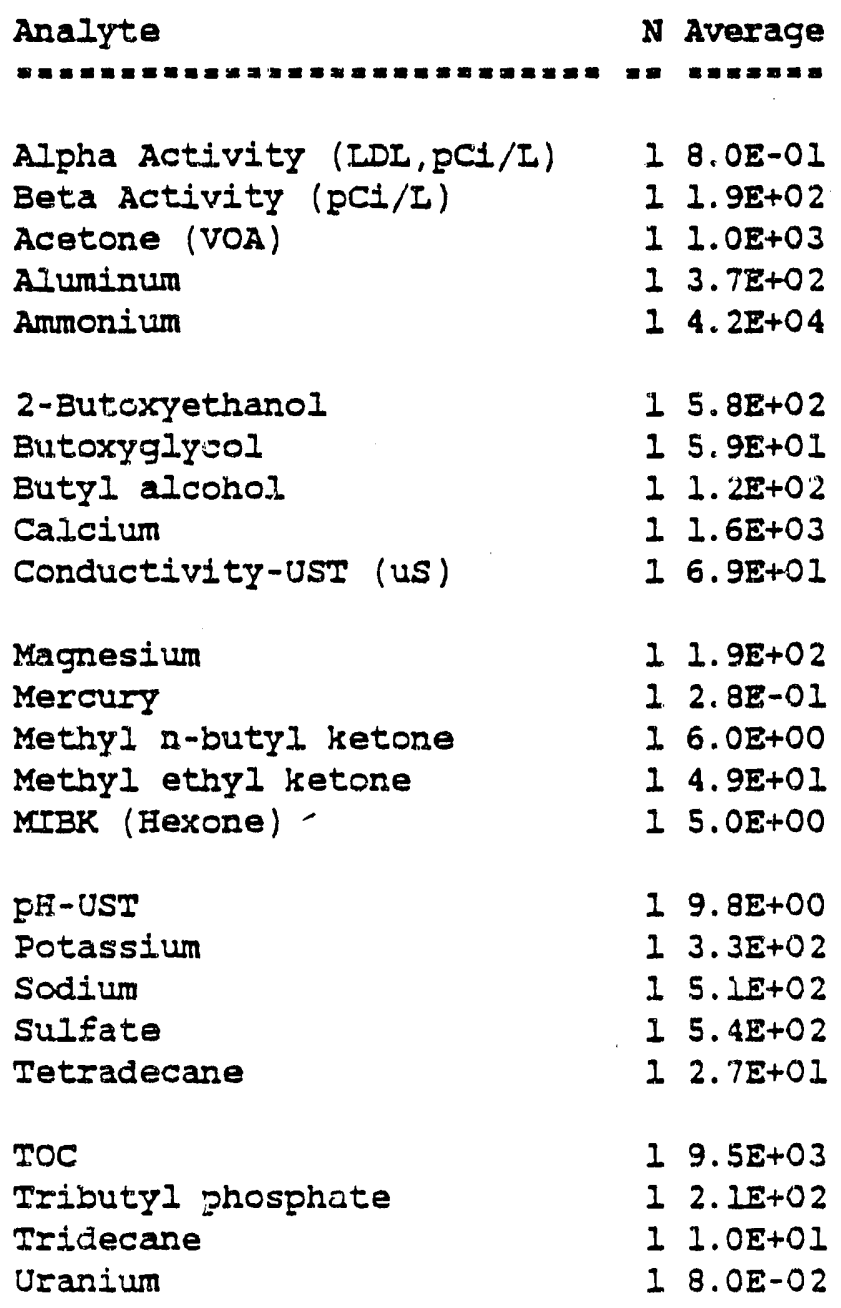


WHC-EP- 0327

242-A Evaporator Process Condensate - Linked Feed Sample ID AP22: 2 UST Samples

Detected Analytes

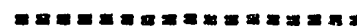

Note: Units are PPB unless otherwise indicated.

inalyte

N Average Kinimum Maximum 90\% CI

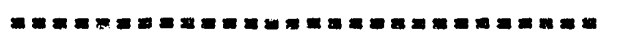

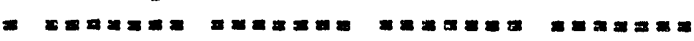

Alpha Activity (IDL, PCI/I)

Beta Activity (PCI/L)

Acetone (VOA)

Aluminum

Ammonium

2-Butoxyethanol

Butoxyglycol

Butraldehyde

Butyl alcohol

Calcium

Conductivity-UST (uS)

Iron

Magnesium

Mercusy

Methyl a-buty l ketone

Methy I ethy I ketone

Methyl n-propyl ketone

MIBKR (Hexone)

pH-UST

Potassium

Sodium

Tetradecane

Tetrahydrofuran

TOC

Tributyl phosphate

Trideciane

Uranium

zinc
$26.3 \mathrm{E}-01 \quad 2.2 \mathrm{E}-01 \quad 1.0 \mathrm{E}+00 \quad 1.9 \mathrm{E}+00$

$21.9 \mathrm{E}+02 \quad 1.8 \mathrm{E}+02 \quad 1.9 \mathrm{E}+02 \quad 2.0 \mathrm{E}+02$

$25.8 \mathrm{E}+02 \quad 4.5 \mathrm{E}+02 \quad 7.1 \mathrm{E}+02 \quad 9.8 \mathrm{E}+02$

$24.4 E+02 \quad 4.2 E+02 \quad 4.7 E+02 \quad 5.2 E+02$

$25.0 \mathrm{E}+04 \quad 3.5 \mathrm{E}+04 \quad 6.6 \mathrm{E}+04 \quad 9.8 \mathrm{E}+04$

$27.4 \mathrm{E}+027.2 \mathrm{E}+02 \quad 7.6 \mathrm{E}+02 \quad 8.0 \mathrm{E}+02$

2 1. $2 \mathrm{E}+02$ 1. $1 \mathrm{E}+02$ 1. $3 \mathrm{E}+02$ 1. $5 \mathrm{E}+02$

$11.9 \mathrm{E}+02$

$24.1 \mathrm{E}+02 \quad 6.6 \mathrm{E}+01 \quad 7.6 \mathrm{E}+02 \quad 1.5 \mathrm{E}+03$

$22.1 \mathrm{E}+03 \quad 1.2 \mathrm{E}+03 \quad 2.9 \mathrm{E}+03 \quad 4.7 \mathrm{E}+03$

$26.8 \mathrm{E}+01 \quad 6.2 \mathrm{E}+01 \quad 7.3 \mathrm{E}+01 \quad 8.4 \mathrm{E}+01$ $13.5 \mathrm{E}+01$

$21.3 \mathrm{E}+02 \quad 1.1 \mathrm{E}+02 \quad 1.5 \mathrm{E}+02 \quad 1.9 \mathrm{E}+02$

2 1.8E-01 1.2E-01 2. $4 \mathrm{E}-01 \quad 3.6 \mathrm{E}-01$

$16.0 \mathrm{E}+00$

$24.5 E+012.2 E+01 \quad 6.9 E+01 \quad 1.2 E+02$

$17.0 \mathrm{E}+00$

$23 . O E+O 0 \quad 3.0 E+O 0 \quad 3.0 E+O 0 \quad 3.0 E+00$

$29.5 \mathrm{E}+00 \quad 9.3 \mathrm{E}+00 \quad 9.8 \mathrm{E}+00 \quad 1.0 \mathrm{E}+01$

$23.0 E+02 \quad 2.3 E+02 \quad 3.6 E+02 \quad 5.1 E+02$

$14.8 \mathrm{E}+02$

2 1. $8 E+01 \quad 1.3 E+01 \quad 2.3 E+01 \quad 3.3 E+0.1$

$11.1 E+01$

$22.4 E+04 \quad 7.0 E+03 \quad 4.1 E+04 \quad 7.7 E+04$

$22.4 E+03 \quad 2.7 E+02 \quad 4.6 E+03 \quad 9.1 E+03$

$21.0 E+01 \quad 7.0 E+00$ 1. $4 E+01 \quad 2.1 E+01$

2 1. 8E-O1 $1.2 E-01 \quad 2.4 E-01 \quad 3.7 E-01$

$15.0 \mathrm{E}+00$ 
WHC-EP-0327

242-A Evaporator Process Condensate - Iinked Feed

Sample ID AP23: 2 UST Samples

Detected Analytes

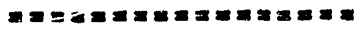

Note: Units arg PPB unless otherwise indicated.

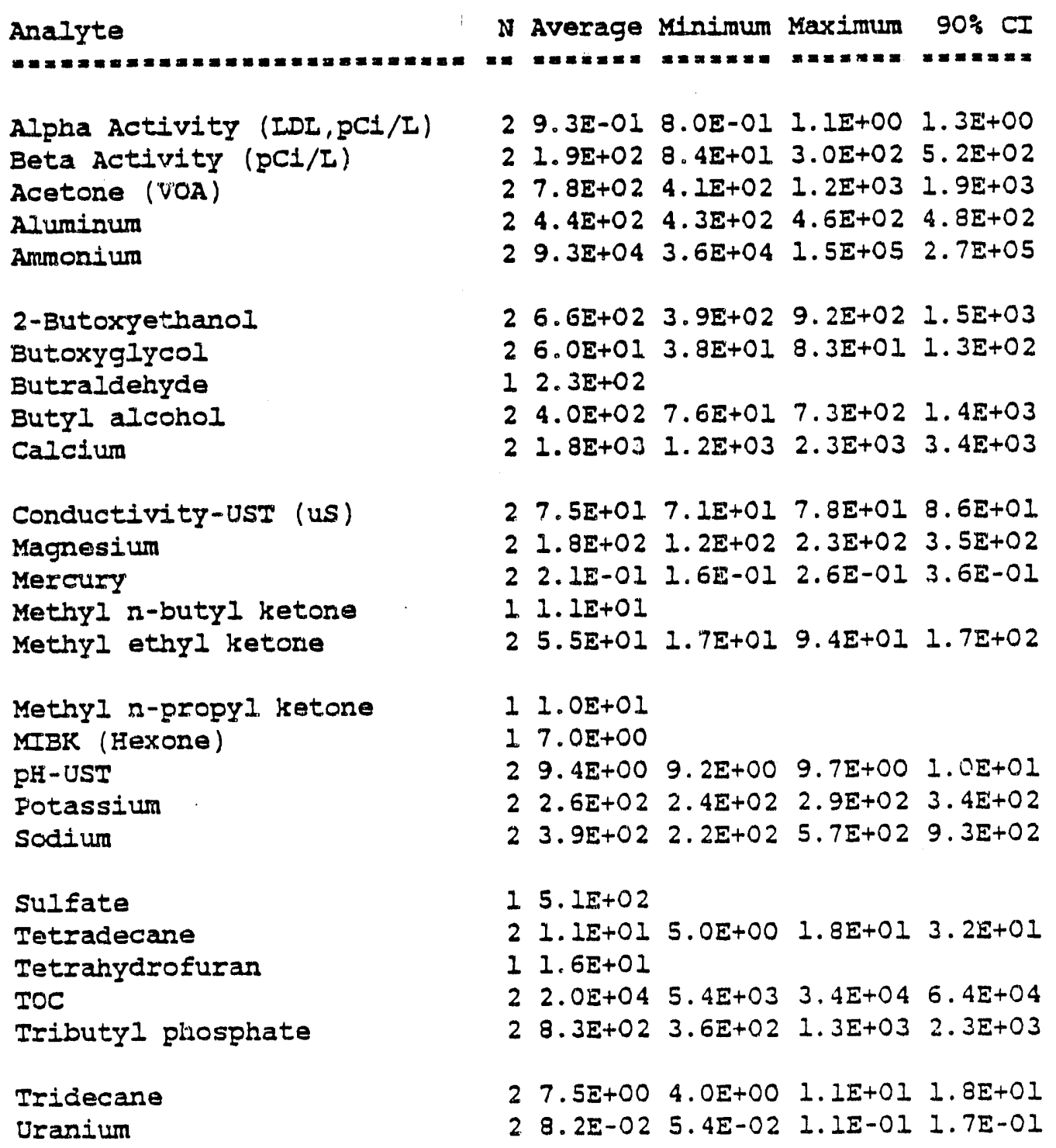


WHC-EP-0327

242-A Evaporator Process Condensate - ASF Feed

Sample ID AP30: 5 UST Samples

Detected Analytes

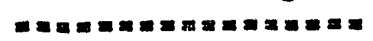

Note: Units are PPB unless otherwise indicated.

Analyte

$n=n=n=n=n=n=n=n=n$
Beta Activity (pCi/I)
Acetone (VOA)
Aluminum
Ammonium
Boron

Butoxydiglycol

Butoxytriethylene glycol

Butyl alcohol

Calcium

Chloride

Conductivity-Field (us)

Fluoride (IC)

Fluoride (ISE)

Iron

Mercury

Methyl n-buty l ketone

Methyl ethyl ketone

2-Methy Inonane

Nickel

$\mathrm{pH}-\mathrm{Field}$

Potassiun

2-Propanol

silicon

Sodium

Strontium

sulfate

Temperature-rield (celsius)

Tetrahydrofuran

TOC

Total Dissolved solids

Tributyl phosphate

Unknown

Unknown aliphatic HC

Uranium

Vanadium
N Average Kinimum Maximum $90 \%$ CI

$\begin{array}{lllll}5 & 3.4 E+03 \quad 4.4 E+01 & 1.2 E+04 & 6.9 E+03\end{array}$

$\begin{array}{lllll}5 & 1.2 \mathrm{E}+03 & 5.8 \mathrm{E}+02 & 2.2 \mathrm{E}+03 & 1.6 \mathrm{E}+03\end{array}$

5 1. $1 \mathrm{E}+03 \quad 6.1 \mathrm{E}+02 \quad 1.8 \mathrm{E}+03 \quad 1.4 \mathrm{E}+03$

$51.2 \mathrm{E}+06 \quad 6.2 \mathrm{E}+05 \quad 2.2 \mathrm{E}+06 \quad 1.6 \mathrm{E}+06$

$11.3 \mathrm{E}+01$

$12.7 \mathrm{E}+01$

$13.5 \mathrm{E}+01$

$32.0 E+03 \quad 1.1 E+02 \quad 5.7 E+03 \quad 5.5 E+03$

$54.2 E+03 \quad 1.8 E+03 \quad 8.3 E+03 \quad 6.0 E+03$

$12.3 E+03$

$24.6 \mathrm{E}+02 \quad 3.3 \mathrm{E}+02 \quad 5.9 \mathrm{E}+02 \quad 8.6 \mathrm{E}+02$

$12.1 E+03$

$24.1 E+01 \quad 3.4 E+01 \quad 4.8 E+01 \quad 6.3 E+01$

$\begin{array}{llllll}2 & 3.7 E+01 & 3.4 E+01 & 4.1 E+01 & 4.8 E+01\end{array}$

2 1.5E-OI 1.2E-0.1 1.8E-O1 2. $4 E-01$

$17.9 \mathrm{E}+01$

$5 \quad 4.7 \mathrm{E}+01 \quad 2.2 \mathrm{E}+01 \quad 9.3 \mathrm{E}+01 \quad 6.6 \mathrm{E}+01$

2 1. $5 E+O I$ 1. $4 E+O I$ 1. $7 E+O I \quad 2.0 E+O I$

$11.4 \mathrm{E}+01$

$21.1 E+01 \quad 1.1 E+01 \quad 1.1 E+01 \quad 1.2 E+01$

$5 \quad 1.5 E+03 \quad 4.4 E+02 \quad 2.5 E+03 \quad 2.1 E+03$

$11.0 E+01$

$37.1 \mathrm{E}+03 \quad 5.7 \mathrm{E}+03 \quad 9.4 \mathrm{E}+03 \quad 9.3 \mathrm{E}+03$

$\begin{array}{lllll}5 & 7.1 \mathrm{E}+03 & 2.6 \mathrm{E}+02 & 3.3 \mathrm{E}+04 & 1.7 \mathrm{E}+04\end{array}$

$31.8 E+O 1$ 1. OE+OI 3.OE+OI $3.0 E+O 1$

$\begin{array}{lllll}5 & 2.0 \mathrm{E}+03 & 1.2 \mathrm{E}+03 & 3.9 \mathrm{E}+03 \quad 2.8 \mathrm{E}+03\end{array}$

$23.2 E+01 \quad 2.9 E+01 \quad 3.5 E+01 \quad 4.1 E+01$

5 4. $4 E+01$ 2.5E+O1 8. $1 E+01 \quad 5.9 E+01$

$53.0 \mathrm{E}+04 \quad 6.2 \mathrm{E}+03 \quad 7.8 \mathrm{E}+04 \quad 5.0 \mathrm{E}+04$

$12.4 \mathrm{E}+04$

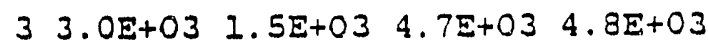

$123.8 \mathrm{E}+02$ 1. $4 \mathrm{E}+01 \quad 2.0 \mathrm{E}+03 \quad 6.4 \mathrm{E}+02$

$11.2 \mathrm{E}+01$

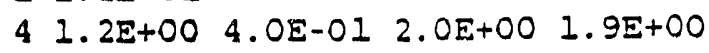

I $\bar{\sigma} . \overline{\mathrm{U}} \overline{\mathrm{E}}+\overline{\mathrm{O}} \overline{\mathrm{O}}$ 
242-A Evaporator Process Condensate - ASE Feed

Sample ID AP30: 5 UST Samples

Detected Analptes

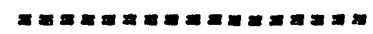

Note: Units are PPB unless otherwise indicated.

Analyte

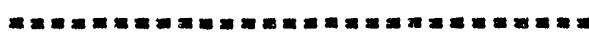

zinc
N Average Minimum Maximum 90\% CI

$21.3 E+011.0 E+011.7 E+012.4 E+01$ 
242-A Evaporator Process Condensate - ASF Feed Sample ID AP31: 4 UST Samples

Detected Analytes

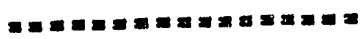

Note: Units are PPB unless otherwise indicated.

Analyte

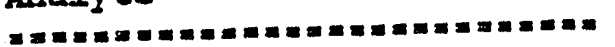

Alpha Activity (IDL,pCI/L) Beta Activity (pci/L)

Acetone (VOA)

Aluminum

Ammonium

Benzyl alcohol

2-Butoxyethanol

Butoxyglycol

Butraldehyde

Butyl alcohol

Calcium
Chloride
Conductivity-UST (US)
Fluoride (ISE)
Iron

Magnesium
Manganese
Mercury
Methyl n-butyl ketone
Methyl ethyl ketone
pH-UST
Potassium
2-Propanol
Stlicon
Sodium
Strontium
Sulfate
Tetradecane
Tetrahydrofuran
ToC
Total Dissolved solids
Tributyl phosphate
Tridecane
Unknown
Üraniuin

N Average Minimum Maximum 90\% CI

$13.18-01$

$\begin{array}{llll}3 & 3.2 \mathrm{E}+03 & 2.5 \mathrm{E}+02 & 8.0 \mathrm{E}+03 \quad 7.8 \mathrm{E}+03\end{array}$

$26.7 \mathrm{E}+02 \quad 4.4 \mathrm{E}+02 \quad 9.0 \mathrm{E}+02 \quad 1.4 \mathrm{E}+03$

$28.6 \mathrm{E}+02 \quad 8.1 \mathrm{E}+02 \quad 9.0 \mathrm{E}+02 \quad 9.9 \mathrm{E}+02$

3 4. $4 E+05$ 1.2E+04 $6.6 E+0 E$ 8. $4 E+05$

$11.7 \mathrm{E}+01$

$22.7 \mathrm{E}+02 \quad 1.1 \mathrm{E}+02 \quad 4.3 \mathrm{E}+02 \quad 7.6 \mathrm{E}+02$

2 1. $8 \mathrm{E}+02 \quad 1.0 \mathrm{E}+02 \quad 2.5 \mathrm{E}+02 \quad 4.0 \mathrm{E}+02$

$15.0 E+00$

$29.6 \mathrm{E}+03 \quad 2.5 \mathrm{E}+02 \quad 1.9 \mathrm{E}+04 \quad 3.8 \mathrm{E}+04$

$3 \quad 3.1 \mathrm{E}+03 \quad 1.8 \mathrm{E}+03 \quad 5.5 \mathrm{E}+03 \quad 5.4 \mathrm{E}+03$

$16.7 \mathrm{E}+02$

$21.9 E+02 \quad 1.2 E+02 \quad 2.8 E+02 \quad 4.6 E+02$

$24.8 \mathrm{E}+01 \quad 3.2 \mathrm{E}+01 \quad 6.5 \mathrm{E}+01 \quad 9.9 \mathrm{E}+01$

$16.7 \mathrm{E}+01$

$17.5 \mathrm{E}+02$

I $5.0 \mathrm{E}+00$

3. 3. $4 \mathrm{E}-01$ 1.5E-O1 5.6E-O1 5.7E-O1

$14.0 E+00$

2 2.1E+OI. 1.8E+OI 2.5E+OI $3.2 \mathrm{E}+01$

$29.5 \mathrm{E}+00 \quad 8.6 \mathrm{E}+00 \quad 1.0 \mathrm{E}+01 \quad 1.2 \mathrm{E}+01$

3 4. $6 \mathrm{E}+03$ 4. $3 \mathrm{E}+02$ 1. $3 \mathrm{E}+04$ 1. $2 \mathrm{E}+04$

$12.3 \mathrm{E}+01$

$15.5 \mathrm{E}+03$

$37.4 E+02 \quad 3.2 E+02 \quad 1.1 E+03 \quad 1.2 E+0.3$

1 1. $1 E+01$

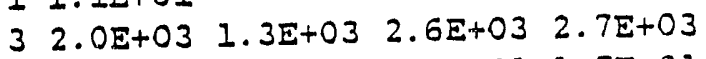

2 1. $4 \mathrm{E}+01$ 1. $3 \mathrm{E}+01$ 1. $1.5 \mathrm{E}+01 \quad 1.7 \mathrm{E}+01$

$21.5 E+01 \quad 1.2 E+01 \quad 1.7 E+01 \quad 2.2 E+01$

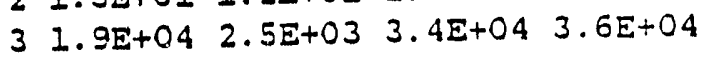

$\begin{array}{llllll}1 & 2.1 E+04 & & & \\ 4 & 3.3 E+03 & 3.1 E+02 & 6.9 E+03 & 5.7 E+03 \\ 2 & 1.0 E+01 & 7.0 E+00 & 1.4 E+01 & 2.1 E+01 \\ 4 & 1.7 E+02 & 9.0 E+00 & 6.3 E+02 & 4.2 E+02 \\ 2 & 3.0 E-01 & 2.4 E-01 & 3.6 E-01 & 4.8 E-01\end{array}$ 
WHC -EP-0327

242-A Evaporator Process Condensate - ASF Feed

Sample ID AP31: 4 UST Samples

Detected Analytes

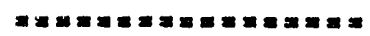

Note: Units are PPB unless otherwise indicated.

Analyto

N Average Minimum Maximum 90\% CI

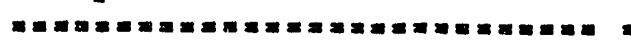

Vanadi"m

zinc

$17.0 \mathrm{E}+00$

$26.5 E+00 \quad 6.0 E+00 \quad 7.0 E+00 \quad 8.0 E+00$ 
242-A Evaporator Process Condensate - ASF Feed

Sample ID AP32: 2 UST Samples

Detected Analytes

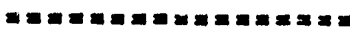

Note: Untts are PPE unless otherwise indicated.

Analyte

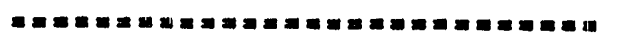

Alpba Activity (IDI,pCI/I)

Beta Activity (pCL/L)

Acetone (VOA)

Aluminum

Ammonium

Barium

Benzyl alcohol

2-Butoxyethanol

Butoxyglycol

Butraldehyde

Butyl alcohol

Calcium

Conductivity-usT (us)

Copper

Fluoride (ISE)

Magnesium

Methyl ethyl ketone

pH-isT

Potassium

sodium

Sulfate

Tetradecane

Tetrahydrofuran

TOC

Tributyl phosphate

Tridecane

Untenown
N Average Minimum Maxiraum 90\% CI

$11.0 \mathrm{E}+00$

$15.1 E+03$

$19.5 \mathrm{E}+02$

$16.3 \mathrm{E}+02$

I $4.5 E+05$

$17.0 \mathrm{E}+00$

2 1. $1 E+01$ 9.0E+00 1.3E+01 1.7E+01

$\begin{array}{lllll}2 & 2.9 \mathrm{E}+02 & 8.5 \mathrm{E}+01 & 4.9 \mathrm{E}+02 & 9.1 \mathrm{E}+02\end{array}$

$22.5 E+02 \quad 1.3 E+02 \quad 3.6 E+02 \quad 6.0 E+02$

$11.3 \mathrm{E}+01$

$26.7 \mathrm{E}+03 \quad 2.6 \mathrm{E}+02 \quad 1.3 \mathrm{E}+04 \quad 2.6 \mathrm{E}+04$

$12.6 \mathrm{E}+03$

$12.6 \mathrm{E}+02$

$11.2 \mathrm{E}+01$

$14.4 \mathrm{E}+01$

$15.3 E+01$

$12.5 E+01$

$11.0 \mathrm{E}+01$

$11.6 \mathrm{E}+04$

$11.9 \mathrm{E}+03$

$12.8 \mathrm{E}+03$

$\begin{array}{lllll}2 & 1.9 E+01 & 1.3 \mathrm{E}+01 & 2.5 \mathrm{E}+01 & 3.7 \mathrm{E}+01\end{array}$

$11.2 \mathrm{E}+01$

$12.3 E+04$

$25.6 E+03 \quad 3.1 E+03 \quad 8.0 E+03 \quad 1.3 E+04$

$22.2 E+01 \quad 1.6 E+01 \quad 2.8 E+O 1 \quad 4.0 E+O 1$

$\begin{array}{lllll}3 & 2.0 E+O I & 9.0 E+00 & 3.2 E+O 1 & 3.3 E+O 1\end{array}$ 
242-A Evaporator Process Condensate - ASF Feed

Sample ID AP33: 2 UST Samples

Detected Analytes

$m= \pm m= \pm m= \pm m= \pm m= \pm$

Note: Units are PPB unless otherwise indicated.

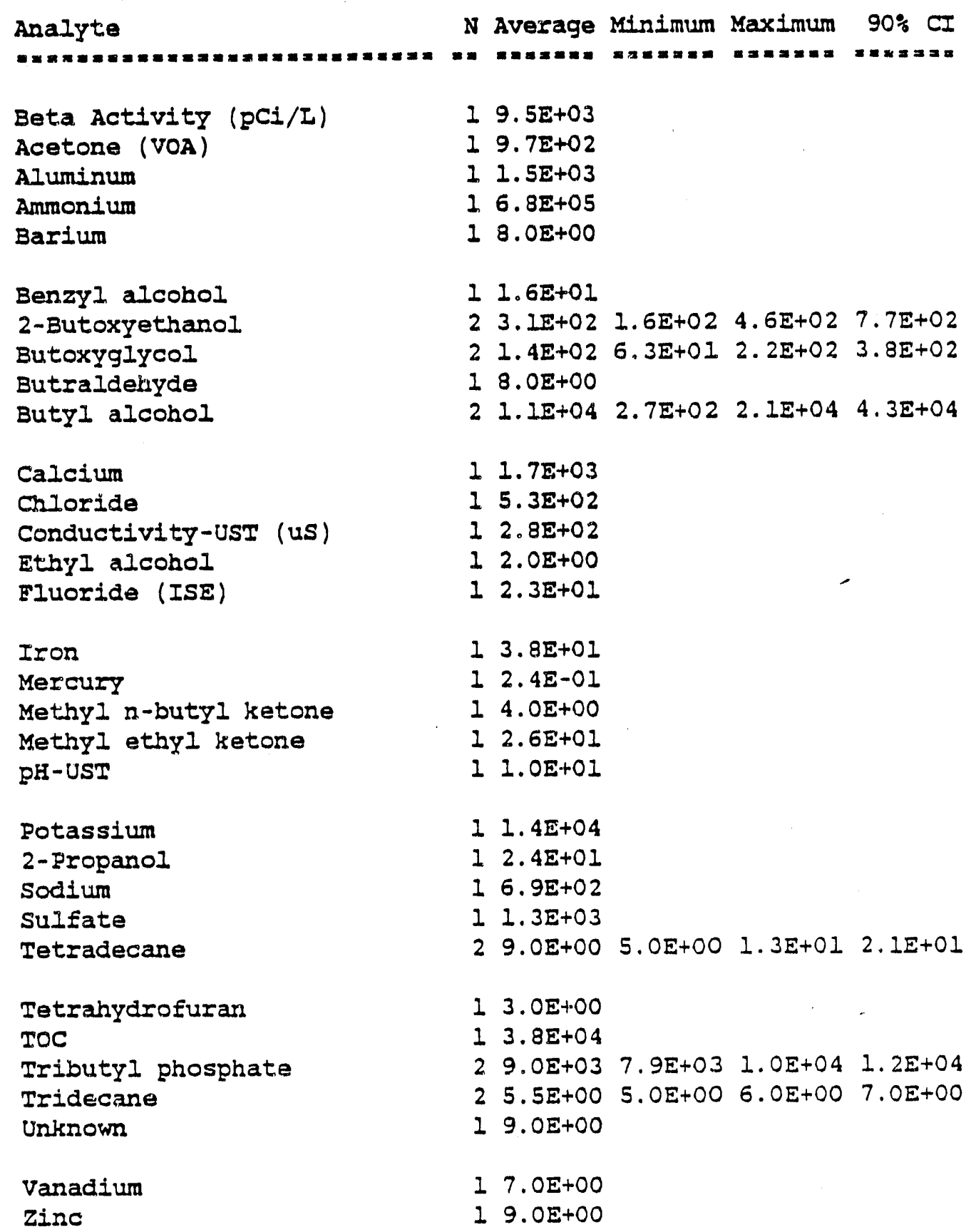


242-A Evaporator Process Condensate - Saltwell Feed

Sample ID AP41: 1 UST Samples

Detected Analytes

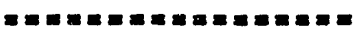

Note: Units are PPB unless otherwise indicated.

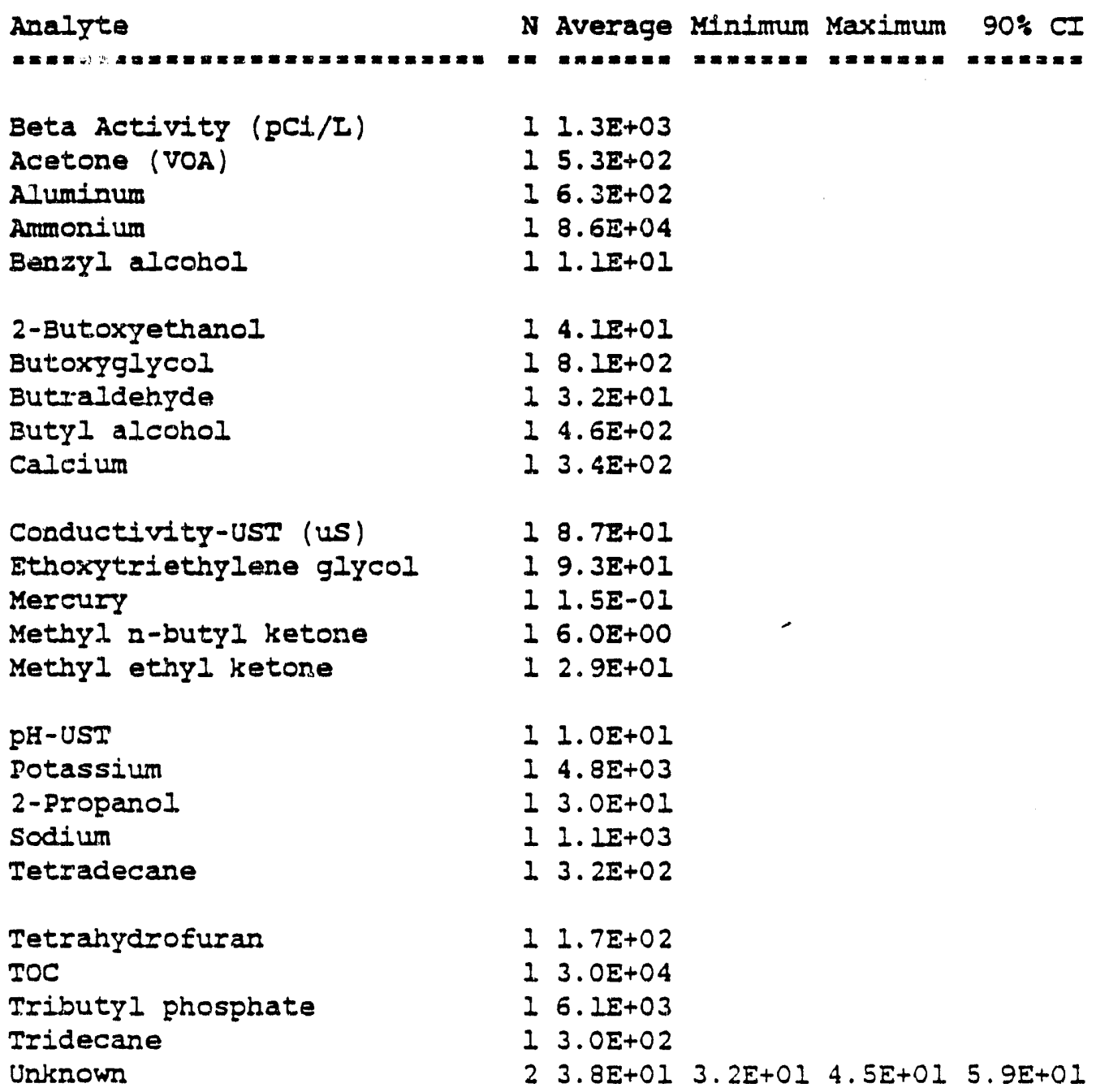


WHC-EP-0327

242-A Evaporator Process Condensate - SaItwell Feed

Sample ID AP42: 2 UST Samples

Detected Analytes

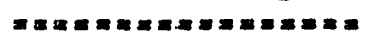

Note: Units are PPB unless otherwise indicated.

Analyte

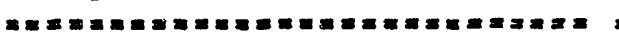

Beta Activity (pCi/L)

Acetone (VOA)

Aluminum

Ammonium

2-Butoxyethanol

Butoxyglycol

Butialdehyde

Butyl alcobol

Salcium

conductivity-UST (us)

Ethoxytriethylene glycol

Mercury

Methoxydiglycol

Methoxytriglycol

Methyl $n$-butyl ketone

Methyl ethyl ketone

pH-UST

potassium

2-Iropanol

sodium

Tetradecane

Tetrahydrofuran

TOC

Tributyl phosphate

Tridecane

Unksown

zine
N Average Minimum Maximum 90\% CI

$21.3 E+03 \quad 9.6 E+021.6 E+03 \quad 2.3 E+03$

2. $7.4 E+026.2 E+028.5 E+02$ 1.1E+03

$25.5 E+025.5 E+025.6 E+025.7 E+02$

$27.2 \mathrm{E}+04 \quad 5.6 \mathrm{E}+048.9 \mathrm{E}+041.2 \mathrm{E}+05$

$29.0 E+018.2 E+019.8 E+011.1 E+02$

$26.6 \mathrm{E}+02 \quad 5.7 \mathrm{E}+027.4 \mathrm{E}+029.2 \mathrm{E}+02$

$11.8 \mathrm{E}+01$

$22.9 E+02 \quad 2.3 E+02 \quad 3.4 E+02 \quad 4.5 E+02$

$23.3 E+02 \quad 2.8 E+02 \quad 3.8 E+02 \quad 4.9 E+02$

$28.0 E+017.7 E+01$ 8. $4 E+019.1 E+01$

$11.2 \mathrm{E}+02$

2 2. IE-OI 2.OE-OI 2.3E-OI 2.6E-OI

$15.2 \mathrm{E}+01$

$16.5 \mathrm{E}+01$

$24.5 E+60 \quad 4.0 E+00 \quad 5.0 E+00 \quad 6.0 E+00$

$22.8 E+012.8 E+012.9 E+01 \quad 3.0 E+O 1$

$21.0 E+019.9 E+001.0 E+01$ 1. $0 E+01$

$24.6 E+034.1 E+035.1 E+036.1 E+03$

$21.5 E+01 \quad 9.0 E+00 \quad 2.1 E+01 \quad 3.3 E+01$

$21.9 E+03 \quad 1.0 E+032.7 E+034.5 E+03$

$27.7 E+0121.4 E+011.4 E+02 \quad 2.7 E+02$

$26.5 E+014.4 E+01$ 8.5E+01 1.3E+02

$22.1 E+041.9 E+042.3 E+04 \quad 2.6 E+04$

$23.1 E+03 \quad 2.0 E+03 \quad 4.1 E+03 \quad 6.3 E+03$

$21.0 E+029.0 E+0 O 2.0 E+02 \quad 4.0 E+02$

$37.1 E+013.9 E+01 \quad 1.3 E+021.3 E+02$

$22.5 E+O 1$ 7. OE+OO 4. $4 E+01$ 8. $2 E+O I$ 
WHC-EF-0327

242-A Evaporator Process Condensate - Saltwell Feed

Sample ID AP43: 1 UST Samples

Detected Analytes

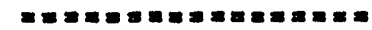

Note: Units are PPB unless otherwise indicated.

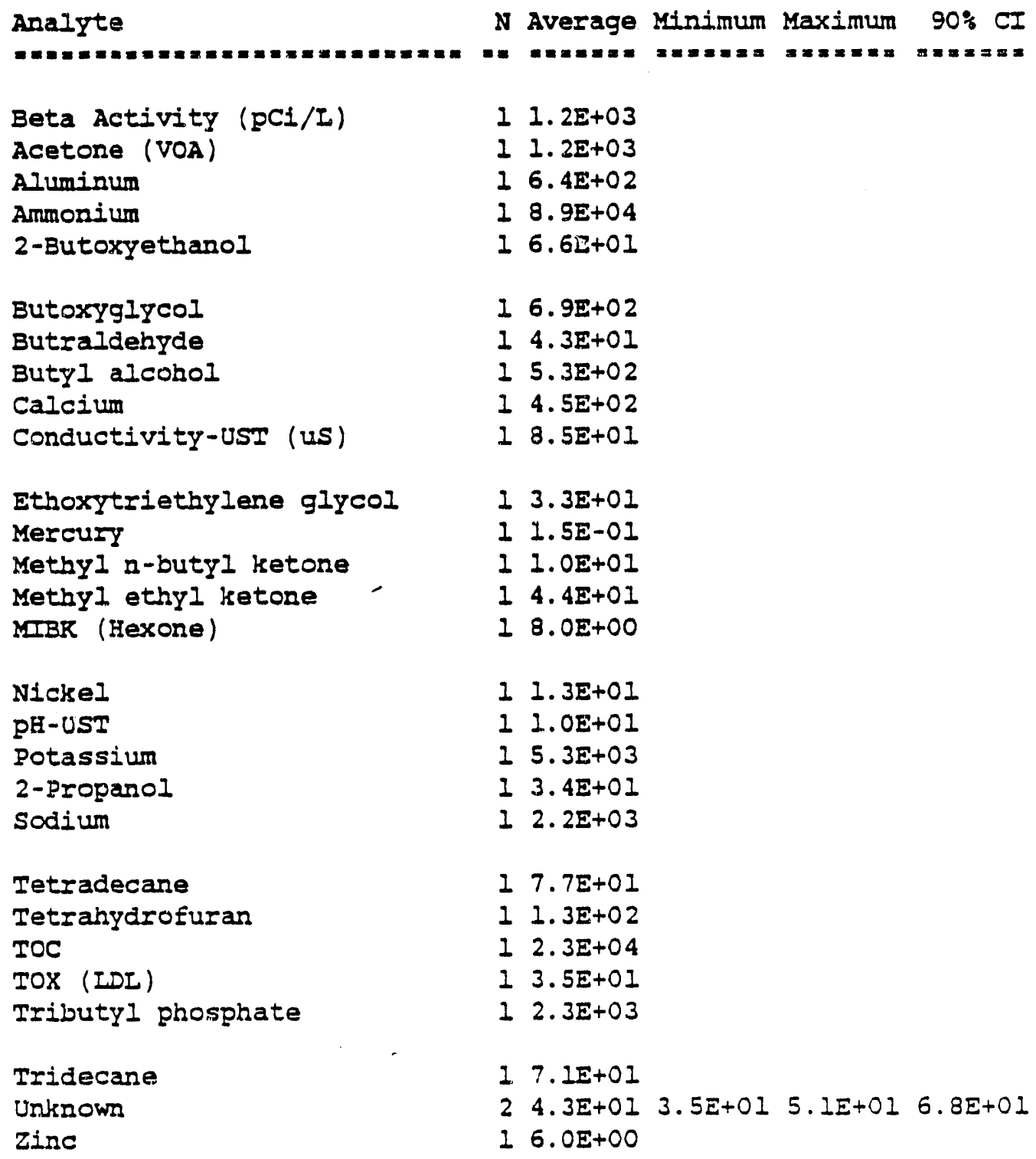


WHC-EP-0327

PROCESS DISTILLATE DISCHARGE STREAM CONSTITUENTS

Chemical/Parameter

Ammonium ( $p p b$ )

Calcium (ppb)

Chromium (ppb)

Magnesium (ppb)

Mercury (ppb)

Potassium (ppb)

Uranium ( $p p b)$

Zinc (ppb)

Sodium (ppb)

Cyanide (ppb)

Sulfate ( $p p b)$

Nitrate (ppb)

Fluoride (ppb)

Butyl Alcohol (ppb)

Butyl Nitrate (ppb)

Decane (ppb)

Dodecane ( $p p b)$

Pentadecane (ppb)

Tetradecane ( $p p b$ )

Tetrahydrofuran (ppb)

Tributylphosphate (ppb)

Tridecane (ppb)

Flow (gpm)

$\mathrm{pH}$

Temperature $\left({ }^{\circ} \mathrm{C}\right)$

Conductivity (US/cm)

Total Organic Carbon

\begin{tabular}{|c|c|c|}
\hline \multicolumn{2}{|c|}{ Range } & \multirow{2}{*}{$\frac{\text { Average }}{11,500}$} \\
\hline 94 & $-\quad 22,900$ & \\
\hline 1400 & $-\quad 5,800$ & 3,600 \\
\hline & $\cdots$ & 14 \\
\hline 300 & $-\quad 780$ & 540 \\
\hline 0.31 & $-\quad 0.41$ & 0.36 \\
\hline 38,720 & $-120,000$ & 57,360 \\
\hline 0.99 & $-\quad 31$ & 18.7 \\
\hline & $\cdots$ & 7 \\
\hline 430 & $-1,400$ & 550 \\
\hline 20 & $-\quad 58$ & 33 \\
\hline 1,700 & $=3,400$ & 2,550 \\
\hline 3,400 & $-12,000$ & 7,450 \\
\hline & $\cdots$ & 750 \\
\hline 14 & 26 & 18 \\
\hline 26 & 75 & 44 \\
\hline & $\cdots$ & 230 \\
\hline 36,000 & $-74,000$ & 55,000 \\
\hline & -- & 3,100 \\
\hline 100,000 & $-210,000$ & 155,000 \\
\hline 14 & $-\quad 24$ & 19 \\
\hline 170,000 & $-180,000$ & 175,000 \\
\hline 130,000 & $-230,000$ & 180,000 \\
\hline 30 & . 60 & 40 \\
\hline 2 & 11.5 & 9 \\
\hline 34.9 & 47.2 & 42.2 \\
\hline 120 & $-\quad 740$ & 377.5 \\
\hline 52,000 & $-110,000$ & 87,000 \\
\hline
\end{tabular}




\section{AMMONIA SCRUBBER DISCHARGE STREAM CONSTITUENTS}

Chemical/Parameter

Ammonium (ppb)

Calcium ( $p p b$ )

Chromium ( $p p b$ )

Magnesium (ppb)

Uranium (ppb)

Zinc (ppb)

Sodium (ppb)

Nickel (ppb)

Chloride (ppb)

Nitrate (ppb)

Benzyl Alcohol (ppb)

Flow (gpm)

$\mathrm{pH}^{\star}$

Temperature $\left({ }^{\circ} \mathrm{C}\right)$

Conductivity (US/cm)

Total Organic Carbon (ppb)
Range

$0 \quad-2.3 \times 10^{6}$

$74-98$

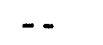

$-\cdot$
Average

360,000

86

13

21

0.33

65

455

11

485

700

12

35

9

32.4

180.5

9,600

\#The ammonium numbers provided include ammonia and ammonium. The concentration of each species is dependent on $\mathrm{pH}$ and temperature. The ammonium and $\mathrm{pH}$ ranges and averages are based on early laboratory results for the ammonia destruction process and are conservative. More recent studies indicate ammonia and ammonium concentrations will normally range from $0.02-0.05 \mathrm{molar}$ and the $\mathrm{pH}$ range will be $6-9.5$. The values shown are to be used for design of transfer and storage systems only. These values are negotiable if additional design requirements result. 
WHC-EP-0327

PUREX PROCESS DISTILLATE DISCHARGE RADIONUCLIDE CONTENT

\begin{tabular}{lcc} 
Isotope & $\begin{array}{c}\text { Average Concentration } \\
(u C i / m 1)\end{array}$ & $\begin{array}{c}\text { Montinly Maximum } \\
\text { Concentration }(u C i / m 1)\end{array}$ \\
\hline Total Alpha & $5.88 \times 10^{-7}$ & $1.38 \times 10^{-6}$ \\
Total Beta & $5.71 \times 10^{-7}$ & $1.52 \times 10^{-6}$ \\
$3_{\mathrm{H}}$ & $3.38 \times 10^{-2}$ & $2.74 \times 10^{-1}$ \\
$90 \mathrm{Sr}$ & $<9.86 \times 10^{-8}$ & $<1.76 \times 10^{-7}$ \\
${ }^{103} \mathrm{Ru}$ & $<3.38 \times 10^{-8}$ & $<4.00 \times 10^{-8}$ \\
$106 \mathrm{Ru}$ & $<4.85 \times 10^{-7}$ & $<1.05 \times 10^{-6}$ \\
$129 \mathrm{I}$ & $<1.21 \times 10^{-7}$ & $3.36 \times 10^{-7}$ \\
$137 \mathrm{Cs}$ & $<4.9 \times 10^{-8}$ & $<5.31 \times 10^{-8}$ \\
$\mathrm{i} 37 \mathrm{Pm}$ & $3.06 \times 10^{-7}$ & $1.20 \times 10^{-6}$ \\
$U \mathrm{Gross}$ & $8.98 \times 10^{-9}$ & $4.41 \times 10^{-8}$ \\
$238 \mathrm{Pu}$ & $9.39 \times 10^{-8}$ & $2.18 \times 10^{-7}$ \\
$239,240 \mathrm{Pu}$ & $6.67 \times 10^{-7}$ & $1.36 \times 10^{-6}$ \\
$241 \mathrm{Pu}$ & $1.12 \times 10^{-5}$ & $2.39 \times 10^{-5}$ \\
$241 \mathrm{Am}$ & $<2.70 \times 10^{-7}$ & $<1.82 \times 10^{-7}$
\end{tabular}


AMMONIA SCRUBBER DISTILLATE RADIONUCLIDE CONTENT

$\begin{array}{lrr}\text { Isotope } & \begin{array}{c}\text { Average Concentration } \\ (u C i / m)\end{array} & \begin{array}{c}\text { Monthiy Maximum } \\ \text { Concentration }(u C i / m)\end{array} \\ \text { Total Alpha } & <8.57 \times 10^{-8} & <1.34 \times 10^{-7} \\ \text { Total Beta } & 2.80 \times 10^{-5} & 8.25 \times 10^{-5} \\ 3_{\mathrm{H}} & 1.41 \times 10^{-3} & 2.27 \times 10^{-3} \\ { }^{90} \mathrm{Sr} & 8.84 \times 10^{-7} & 4.24 \times 10^{-6} \\ 103_{\mathrm{Ru}} & <4.06 \times 10^{-8} & <6.00 \times 10^{-8} \\ 106 \mathrm{Ru} & 1.53 \times 10^{-5} & 7.51 \times 10^{-5} \\ 129 \mathrm{I} & <3.64 \times 10^{-8} & <1.01 \times 10^{-7} \\ 137 \mathrm{Cs} & 3.31 \times 10^{-6} & 5.20 \times 10^{-6} \\ 147 \mathrm{Pm} & 1.59 \times 10^{-6} & 4.70 \times 10^{-6} \\ 239,240 \mathrm{Pu} & <5.53 \times 10^{-8} & 1.48 \times 10^{-7} \\ 241 \mathrm{Pu} & <9.35 \times 10^{-7} & 2.61 \times 10^{-6} \\ 241_{\mathrm{Am}} & <4.13 \times 10^{-7} & <4.84 \times 10^{-7}\end{array}$


CIib Waste Management System Wastestream ActivitY Characteristics Units in $\mathrm{pCi} / \mathrm{L}$

Stream Code: PP

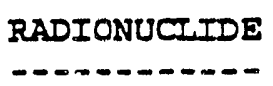

AITHA

BEIA

SR -90

RU -106

$R U-103$

CS -134

CS- 137

PM- 147

U (GROSS)

$\mathrm{H}-3$

AM- 241

$I-129$

PU. 238

PU -241

PU -239
PUREX Process Condensate Activity from 1981 through 1988
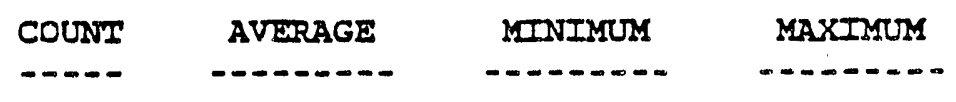

90\% CI IIMITI

\section{5}

1. $0 E+05$

1. $4 E+01$

5. $9 E+06$

1. $2 E+02$

1. $2 \mathrm{E}+07$

9. $O E+0 O$

5. OE+O2

4. $3 E+02$

7. $2 \mathrm{E}+03$

4. $8 \mathrm{E}+05$

1. $9 \mathrm{E}+01$

1. $9 E+03$

8. 8E-03

1. $0 E+04$

8. 8E-03

2. $8 \mathrm{E}+01$

9. $2 E+05$

2. $9 E+01$

2. $8 E+04$

8. 2E-0I

4. $4 E+02$

2. $6 \mathrm{E}+02$

1. $8 \mathrm{E}+08$

4. $7 \mathrm{E}+01$

2. $9 \mathrm{E}+04$

7. $2 \mathrm{E}+01$

1. $0 \mathrm{E}+01$

2. $5 \mathrm{E}+02$

3. $7 \mathrm{E}+03$

2. $4 \mathrm{E}+04$

2. $9 E+06$

2. 2E-03

1. $1 E+05$

2. $2 \mathbf{E}+05$

4. $9 \mathrm{E}+05$

8. $5 \mathrm{E}+02$

5. $5 \mathbf{E}+04$

2. $7 E+03$

$\mathrm{N} / \mathrm{A}$

8. $8 E+04$

4. $2 E+03$

6. $4 E+01$

6. $9 E+07$

1. $2 E+04$

7. $8 E+02$

2. $2 \mathrm{E}+03$

1. $9 \mathrm{E}+05$

7. $3 \mathrm{E}+03$

Less-Than Data Values Have Been Omitted 
PUREX Process Condensatio

Sample ID P100: 8 UST Samples

Detected Analytes

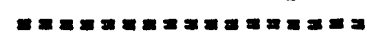

Note: Units are PPB unless otherwise indicated.

Analyte

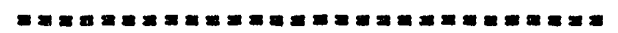

Alpha Activity (LDL, pCI/L)

Beta Activity (pCi/L)

Acetone (VOA)

Ammonium

Bariun

Butraldehyde

Butyl alcohol

Butylnitrate

Cadmium

Calcium

Chloride

Chromium

Conductivity-gield (uS)

Copper

cyanide

Decane

Dodecane

Eluoride (IC)

Iron

Isophorone

Magnesium

Manganese

Mercury

N-Methoxymethanamine

Methylene chloride

Methyl ethyl ketone

Methyl nitrate

Methyl vinyl ketone

Nickel

Nitrate

Nitromethane

Pentadecane

pH-Field

Potassium

sodium
N Average Minimum Maximum 90\% CI

$\begin{array}{lllll}8 & 3.1 \mathrm{E}+02 & 6.3 \mathrm{E}+00 \quad 1.3 \mathrm{E}+03 \quad 5.7 \mathrm{E}+02\end{array}$

8 1. $3 \mathrm{E}+04 \quad 3.1 \mathrm{E}+01 \quad 6.8 \mathrm{E}+04 \quad 2.5 \mathrm{E}+04$

6 4.5E+02 1. $1 \mathrm{E}+02 \quad 9.5 \mathrm{E}+02 \quad 6.8 \mathrm{E}+02$

$\begin{array}{lllll}2 & 1.1 \mathrm{E}+02 & 9.4 \mathrm{E}+01 & 1.3 \mathrm{E}+02 & 1.8 \mathrm{E}+02\end{array}$

$\begin{array}{lllll}3 & 1.3 \mathrm{E}+01 & 6.0 \mathrm{E}+00 & 2.2 \mathrm{E}+01 & 2.2 \mathrm{E}+01\end{array}$

$21.5 \mathrm{E}+01$ 1.2F+OO1 $1.8 \mathrm{E}+01 \quad 2.4 \mathrm{E}+01$

6 2. $8 \mathrm{E}+01$ 1. $4 \mathrm{E}+01 \quad 5.0 \mathrm{E}+01 \quad 3.5 \mathrm{E}+01$

$\begin{array}{lllllll}5 & 8.0 \mathrm{E}+01 & 2.6 \mathrm{E}+01 & 2.4 \mathrm{E}+02 & 1.4 \mathrm{E}+02\end{array}$

$19.0 \mathrm{E}+00$

$\begin{array}{lllll}5 & 6.4 E+03 & 7.6 E+01 & 2.1 E+04 & 1.2 E+04\end{array}$

$4 \quad 4.2 E+03 \quad 1.1 E+03 \quad 7.8 E+03 \quad 6.9 E+03$

$11.4 E+01$

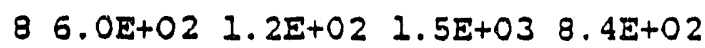

$11.3 E+01$

$5 \quad 5.9 \mathrm{E}+01 \quad 2.0 \mathrm{E}+01$ 1. $4 \mathrm{E}+02 \quad 9.2 \mathrm{E}+O 1$

$12.3 \mathrm{E}+02$

$7 \quad 2.0 \mathrm{E}+04 \quad 8.5 \mathrm{E}+01 \quad 7.4 \mathrm{E}+04 \quad 3.5 \mathrm{E}+04$

$\begin{array}{lllll}2 & 2.4 E+03 & 7.5 E+02 & 4.0 E+03 & 7.3 E+03\end{array}$

$\begin{array}{lllll}2 & 2.2 E+C 2 & 2.1 E+02 & 2.3 E+02 & 2.5 E+02\end{array}$

1. 1. $3 E+O 1$

$\begin{array}{llll}5 & 1.3 \mathrm{E}+03 & 1.9 \mathrm{E}+01 \quad 4.6 \mathrm{E}+03 \quad 2.6 \mathrm{E}+03\end{array}$

$11.2 \mathrm{E}+01$

$\begin{array}{lllll}8 & 2.1 \mathrm{E}+00 & 1.5 \mathrm{E}-01 & 9.0 \mathrm{E}+00 & 3.9 \mathrm{E}+00\end{array}$

$11.2 E+02$

$23.6 E+O 1$ 1.3E+O1 $6.0 E+01 \quad 1.1 E+O 2$

$4 \quad 4.4 E+O I$ 1. $4 E+O I \quad 9.0 E+O 1 \quad 7.2 E+O 1$

$12.4 E+02$

$12.2 \mathrm{E}+\mathrm{OI}$

$11.0 E+01$

$83.0 E+05 \quad 2.0 E+03 \quad 1.7 E+06 \quad 6.0 E+05$

$18.0 \mathrm{E}+00$

$\begin{array}{lllll}3 & 1.9 E+03 & 3.0 E+02 & 3.1 E+03 & 3.5 E+03\end{array}$

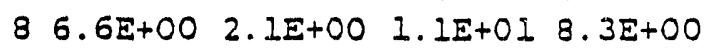

6 8. $3 E+04 \quad 2.3 E+03 \quad 2.6 E+05 \quad 1.4 E+05$

$\begin{array}{lllll}8 & 9.4 E+02 & 1.2 E+02 & 2.2 E+03 & 1.3 E+03\end{array}$

A-29 
WHC-EP-0327

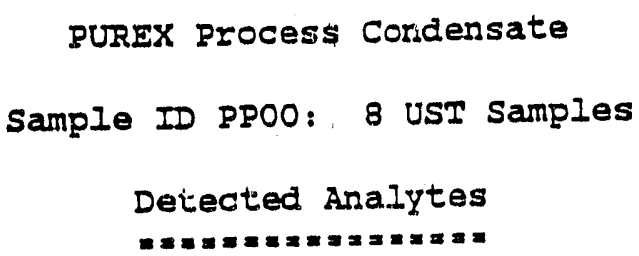

Note: Units are PPB unless otherwise indicated.

\begin{tabular}{|c|c|c|c|c|c|}
\hline 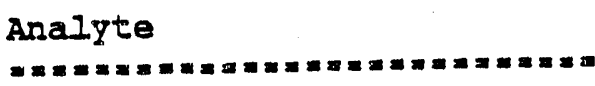 & $\mathrm{N}$ & $\begin{array}{l}\text { Average } \\
=x=x=x=\end{array}$ & Minimum & Maximum & $90 \%$ CI \\
\hline Sulfate & 5 & $3.9 \mathrm{E}+03$ & $6.3 \mathrm{E}+02$ & $1.2 \mathrm{E}+04$ & $7.3 E+03$ \\
\hline lemperature-Field (celsius) & 8 & $4.0 E+O 1$ & $2.0 E+01$ & $4.8 E+01$ & $4.5 E+01$ \\
\hline Tetradecane & 7 & $5.5 E+04$ & $4.4 E+02$ & $2.0 E+05$ & $9.7 E+04$ \\
\hline Tetrahydrofuran & 2 & $1.9 \mathrm{E}+01$ & $1.4 E+01$ & $2.4 E+01$ & $3.4 \mathrm{E}+01$ \\
\hline TOC & 10 & $6.0 E+04$ & $1.9 E+04$ & $1.5 \mathrm{E}+05$ & $7.9 \mathrm{E}+04$ \\
\hline TOX & 1 & $2.7 E+02$ & & & \\
\hline $\operatorname{TOX}(I D I)$ & 3 & $1.0 \mathrm{E}+02$ & $4.8 E+01$ & $2.1 \mathrm{E}+02$ & $2.0 E+02$ \\
\hline Tributyl phosphate & 8 & $1.0 \mathrm{E}+05$ & $9.5 \mathrm{E}+03$ & $1.8 \mathrm{E}+05$ & $1.3 E+05$ \\
\hline Tridecane & 7 & $6.2 E+04$ & $4.3 E+02$ & $2.3 E+05$ & $1.1 E+05$ \\
\hline Undecane & 2 & $7.4 \mathrm{E}+02$ & $5.2 \mathrm{E}+02$ & $9.5 \mathrm{E}+02$ & $1.4 E+03$ \\
\hline Untrnown & 4 & $5.2 \mathrm{E}+03$ & $5.5 \mathrm{E}+02$ & $9.7 \mathrm{E}+03$ & $9.0 \mathrm{E}+03$ \\
\hline Urantum & 11. & $2.2 E+01$ & $9.9 \mathrm{E}-01$ & $5.9 E+01$ & $3.0 E+01$ \\
\hline Lnc & 3 & $1.5 E+01$ & $7.0 E+00$ & $3.2 E+O I$ & $3.1 E+01$ \\
\hline
\end{tabular}


PURFX Process Condensate

Sample ID PPOO: 8 UST Samples

Detected Analytes

Note: Units are PPB unless otherwise indicated.

Analyte

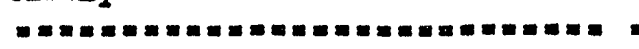

Alpha Activity (LDL,pC1/L) Beta Activity ( $\mathrm{pCl} / \mathrm{L}$ )

Acetone (VOA)

Ammontum

Barium

Butraldehyde

Butyl alcohol

Butylnitrate

Cadmium

Calcium

Chloride
Chromium
Conductivity-Field (us)
Copper
Cyanide

Decane

Dodecane

Fluoride (IC)

Iron

Isophorone

Magnesium

Manganese

Mercury

N-Methoxymethanamine

Methylene chloride

Methyl ethyl ketone

Methyl nitrate

Methyl vinyl ketone

Nickel

Nitrate

Nitromethane

Pentadecane

pH-Field

Potassium

Söiiuin
N Average Minimum Maximum 90\% CI

$83.1 E+02 \quad 6.3 E+00 \quad 1.3 E+03 \quad 5.7 E+02$

$81.3 \mathrm{E}+04 \quad 3.2 \mathrm{E}+01 \quad 6.8 \mathrm{E}+04 \quad 2.5 \mathrm{E}+04$

$6 \quad 4.5 \mathrm{E}+02 \quad 1.1 \mathrm{E}+02 \quad 9.5 \mathrm{E}+02 \quad 6.8 \mathrm{E}+02$

2 1. $1 \mathrm{E}+02$ 9. $4 \mathrm{E}+01 \quad 1.3 \mathrm{E}+02 \quad 1.8 \mathrm{E}+02$

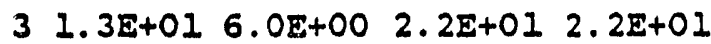

2 1. $5 \mathrm{E}+01 \quad 1.2 \mathrm{E}+01 \quad 1.8 \mathrm{E}+01 \quad 2.4 \mathrm{E}+01$

$62.8 \mathrm{E}+01$ 1. $4 \mathrm{E}+01 \quad 5.0 \mathrm{E}+01 \quad 3.5 \mathrm{E}+01$

$\begin{array}{lllll}5 & 8.0 \mathrm{E}+01 & 2.6 \mathrm{E}+01 & 2.4 \mathrm{E}+02 & 1.4 \mathrm{E}+02\end{array}$

$19.0 \mathrm{E}+00$

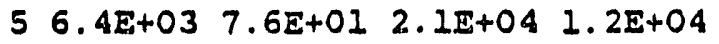

$4 \quad 4.1 E+03 \quad 1.1 E+03 \quad 7.8 E+03 \quad 6.9 E+03$

$11.4 \mathrm{E}+01$

$8 \quad 6.0 \mathrm{E}+02 \quad 1.2 \mathrm{E}+02 \quad 1.5 \mathrm{E}+03 \quad 8.4 \mathrm{E}+02$

$11.3 E+01$

$5 \quad 5.9 E+01 \quad 2.0 E+01 \quad 1.4 E \div 02 \quad 9.2 E+01$

$12.3 \mathrm{E}+02$

$72.0 E+04 \quad 8.5 E+01 \quad 7.4 E+04 \quad 3.5 E+04$

$22.4 E+03 \quad 7.5 E+02 \quad 4.0 E+03 \quad 7.3 E+03$

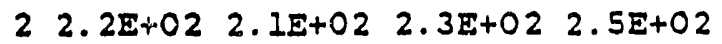

1 1. $3 E+01$

$\begin{array}{llll}5 & 1.3 \mathrm{E}+03 & 1.9 \mathrm{E}+01 \quad 4.6 \mathrm{E}+03 \quad 2.6 \mathrm{E}+03\end{array}$

$11.2 E+01$

8 2. $1 E+00 \quad 1.5 E-01 \quad 9.0 E+00 \quad 3.9 E+00$

$11.2 E+02$

$23.6 \mathrm{E}+01 \quad 1.3 \mathrm{E}+01 \quad 6.0 \mathrm{E}+01 \quad 1.1 \mathrm{E}+02$

$4 \quad 4.4 E+01$ 1. $4 E+01 \quad 9.0 E+01 \quad 7.2 E+01$

$12.4 E+02$

$12.2 E+01$

$11.0 \mathrm{E}+01$

$83.0 E+05 \quad 2.0 E+03 \quad 1.7 E+06 \quad 6.0 E+05$

$18.0 E+00$

3 1. $9 E+03 \quad 3.0 E+02 \quad 3.1 E+03 \quad 3.5 E+03$

$\begin{array}{lllll}8 & 6.6 \mathrm{E}+00 & 2.1 \mathrm{E}+00 & 1.1 \mathrm{E}+01 & 8.3 \mathrm{E}+00\end{array}$

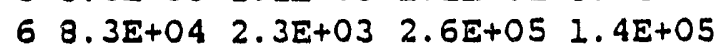

o $3.4 E+02$ i. $2 E+02 \quad 2.2 E+03$ 1. $3 E \div 03$

A-31 


\section{Appendix A6}

The PUREX ammonia scrubber condensate is produced by the Flil concentrator at the Head End of PUREX. The feed to this concentrator is associated with fuel decladding, metathesis, and the transfer of cladding-removal waste to underground storage tanks. Since November 1987, the feed to this concentrator is not being concentrated but is being stored in underground tanks. Since the feed is not being concentrated, the discharge is inactive. Sample data that appear later in this report are defective; only waste associated with fuel decladding were collected and these were not collected when this batch process was releasing ammonia at its maximum rate.

\section{RADIONUCLIDES}

Process Knowledge

Previously Detected: H-3, Sr-90, Ru-103, Ru-106, Sn-113, I-129, Cs-137, $\mathrm{Pm}-147, \mathrm{Pu}-239 / 240, \mathrm{Pu}-241, \mathrm{Am}-241$

Sampled

At: $\quad$ Building 295-A

Every: Week for monthly composite(When the waste is cribbed)

By: Flow proportional sampler

Remark: Waste stream diverted to tanks since November 1987

Analyzed

At:

$$
\text { 222-S Laboratory, Westinghouse Hanford Company }
$$

\section{CHEMICALS}

Varies by: Batch

Scheduled by: Random days, Not coordinated with maximum ammonia release

Process Configuration(Code) Routine Operation(PHO)

Sampling Point(Code) Building 295-A(PHOO)

Anaiyzed

At:

United States Testing Laboratory-Richland 


\section{PUREX Ammonja Scrubber Condensate \\ Sample ID PHOO: 4 UST Samples \\ Detected Analytes}

Note: UnIts are PPB unless otherwise indicated.

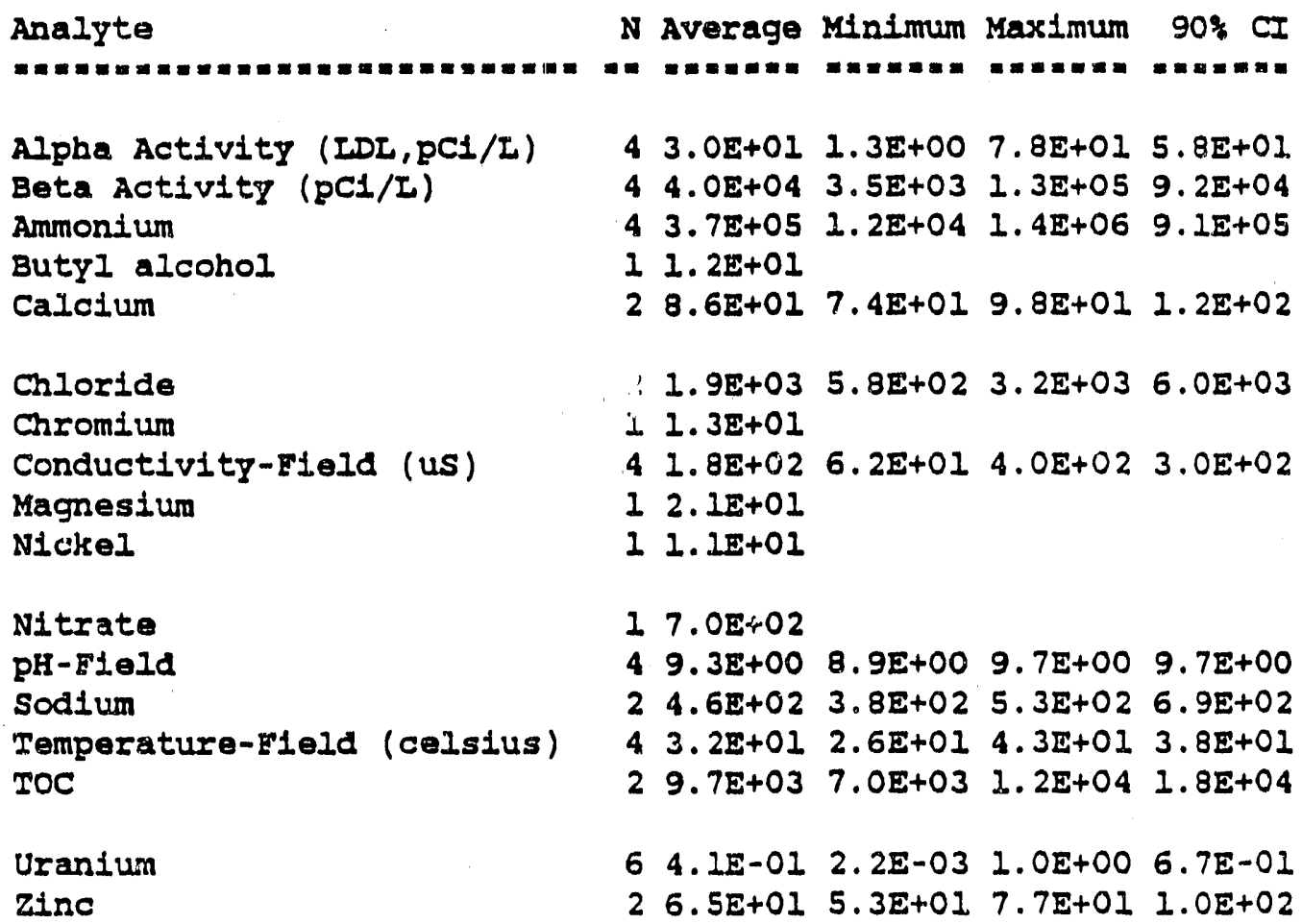


WHC-EP-0327

APPENDIX B

PREFERRED BASIN

B-1 


\section{APPENDIX B \\ PREFERRED BASIN}

\section{B.1 COVER}

Each storage cell will have a floating cover. The covers will be capable of venting trapped gas from behind the cover. Portable or permanent equipment for removing accumulated precipitation on the liner will be provided. Care will be taken in designing the precipitation removal system to minimize damage to the cover and liners. Removal of sand and dirt will not be necessary: in that area, wind will be sufficient to remove sand and dirt from the cover

\section{B.2 TOP COMPOSITE LINER}

The top composite liner will consist of a High-Density Polyetnylene (HDPE) liner or a Westinghouse Hanford Company (Westinghouse Hanford) Defense Waste Engineering, Safety, and Quality Assurance (QA) approved equal that will be placed over a 12- to 18-in. layer of low-permeability soil. This soil will have an in-place saturated hydraulic conductivity of $1 \times 10^{-7} \mathrm{~cm} /$ second or less. The reason a low-permeability soil layer is added as part of the composite liner is so that if a hole is present in the liner the leachate has to migrate through the low-permeability clay before it reaches the drain layer. This reduces the volume of leachate and increases the migration time.

The top liner will be constructed of at least 60-mil Die-cast HDPE or Westinghouse Hanford Defense Waste Engineering, Safety, and QA approved equal. Vendors are required to provide certification confirming compliance to bid specification to Westinghouse Hanford before the bid is awarded. Also, a list of similar projects completed in which the manufactured material has been successfully used will be submitted with the certifications.

Seaming of HDPE sheets will be by a hot-wedge double-fusion weld or Westinghouse Hanford Defense Waste Engineering, Safety, and QA approved equal. Material added during hot-wedge double-fusion welds will be identical to the liner material. Where this seaming technique is impractical, extrusion welding or other Westinghouse Hanford Defense Waste Engineering, Safeiy, and QA-approved seaming technique is to be used. The liner will be installed with sufficient slack to compensate for thermal expansion and contraction caused by ambient temperature variations (-40 of to $\left.+115^{\circ} \mathrm{F}\right)$.

The edge of the liner will be anchored around the entire perimeter of each basin cell but not so tightly that thermal contraction could damage the liner. The liner will extend down the side, across the bottom, and up the opposite side to the anchors. The backfill material used for anchoring will be original soil, free of rock, fractured stone, cobbles, rubbish, and roots or Foreign material. Alternate anchoring methods will be approved by Westinghouse Hanford Defense Waste Engineering, Safety, and Q QA. 
All hot-wedge double-fusion welds will be pneumatically pressure tested to at least $30 \mathrm{lb} / \mathrm{in}^{2}$ (gauge). Pressure will stabilize at $25 \mathrm{lb} / \mathrm{in}^{2}$ (gauge) or greater and hold without loss for a minimum of 15 minute.

Procedures for vacuum testing all other seams will be submitted to Westinghouse Hanford Defense Waste Engineering, Safety, and QA for approval.

The low-permeability soil will be installed over the first leachate collection and removal system. It is recommended that the first lift of soil be 12 in. to avoid damage to the second composite liner and the leachate collection and removal system. Each lift will be properly scarificated in preparation for the next. The necessary precautions will be taken to ensure that the desired moisture content is maintained in the compacted liner to avoid desiccation cracking. The compacted, low-permeability soil must be free of rock, fractured stone, cobbles, rubtish, and roots or foreign material that would increase hydraulic conductivity or serve to promote preferential leachate flow paths.

\section{B. 3 LEACHATE COLLECTION AND REMOVAL SYSTEM}

The leachate collection and removal system will be installed between the second composite liner and the first composite liner. The leachate collection and removal system will either have at least a 12 -in-thick granular drainage layer (hydraulic conductivity not less than

$1 \times 10^{-2} \mathrm{~cm} /$ second) or a high permeable synthetic net (transmissivity not les: than $\left.5 \times 10^{-4} \mathrm{~m}^{2} / \mathrm{second}\right)$. The minimum bottom slope will not be less than $2 \%$.

This system will have the appropriate size pipe and spacing on the bottom of each basin cell to efficiently collect leachate. The pipe materials will be chemically resistant to the waste and leachate. The piping system will also be strong enough to withstand the weight of the waste material and construction equipment placed on top of it.

The leachate collection and removal system will be overlain by a graded granular filter or synthetic fabric filter. This is to prevent clogging of the voids in the drain layer. If a granular filter is used, it is importan: that the relationship of filter medium grain size and he drainage layer be appropriate.

A sump with submersible pumps will be installed at the low end of the basin for each basin cell. Piping will be installed to return the fluid in the leachate system back to the basin. Inspection of the basin and the leachate collection and removal system is required to ensure that the system is operating properly. Additionai leak protection under each sump will be included in the basin design.

A passive gas removal system will also be installed in the side slopes of each basin cell in the drainage layer. Its purpose is to remove gas bubbles from between the liners that may accumulate after completion of construction. 


\section{B.4 BOTTOM COMPOSITE LINER}

The composite liner will consist of a upper 45 mil or greater Die-cast HDPE (similar in construction and material to the cover and top composite liner) and a 36-in-thick (or greater) layer of compacted, emplaced, lowpermeability soil with an in-place saturated hydraulic conductivity of $1 \times 10^{-7} \mathrm{~cm} /$ second or less. The compacted 36 -in-thick soil will be backfilled with a $2 \%$ minimum bottom slope to allow proper drainage of leachate and removal system.

The upper portion of the composite liner will be constructed and meet al1 the requirements of the top liner as previously stated. The vendor will demonstrate their installation technique before installation.

The compacted, low-permeability soil must be free of rock, fractured stone, cobbles, rubbish, and roots or foreign material that would increase hydraulic conductivity or serve to promote preferential leachate flow paths. Lifts will not exceed $g$ in. before compaction to maximize the effectiveness of compaction throughout the lift thickness. Each lift will be properly scarified in preparation for the next. The necessary precautions will be taken to ensure that the desired moisture content is maintained in the compacted liner to avoid desiccation cracking.

The foundation subsoil that underlies the compacted low-permeability soil component will be structurally immobile during construction and operation of the cell (including the postclosure monitoring period). 
Figure B-1. A Surface Impoundment.

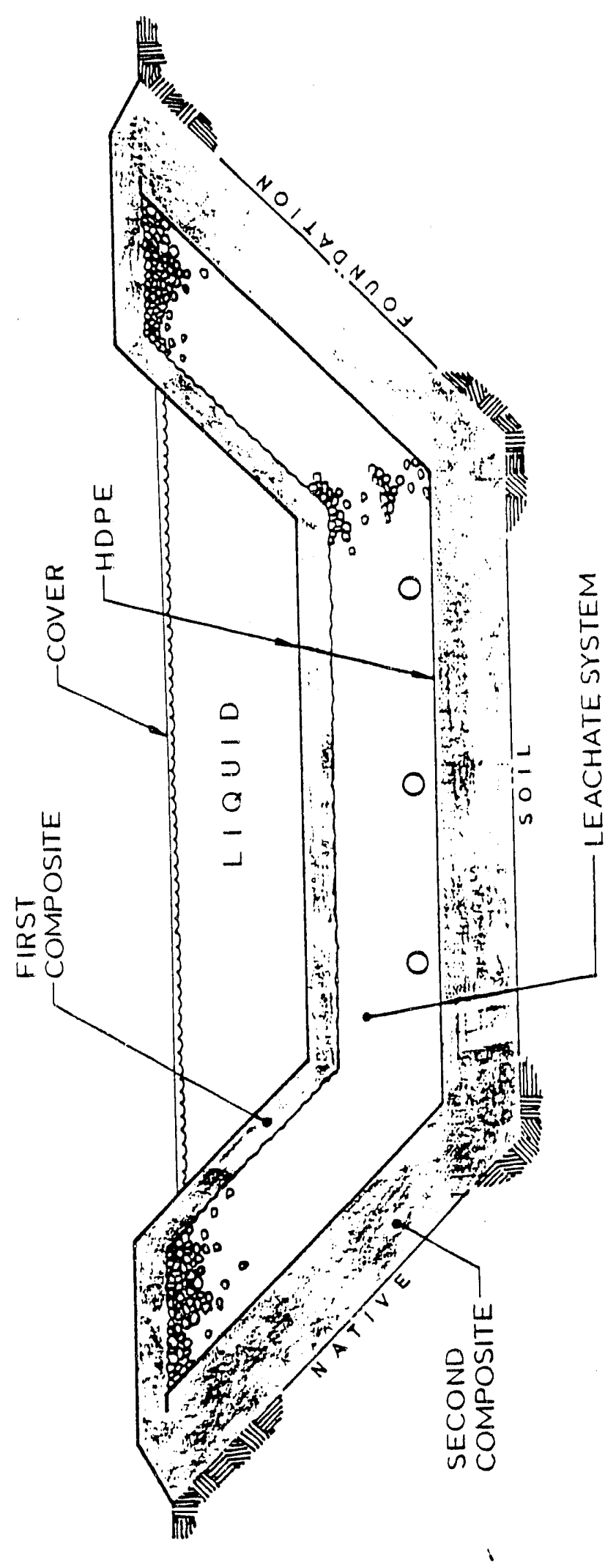



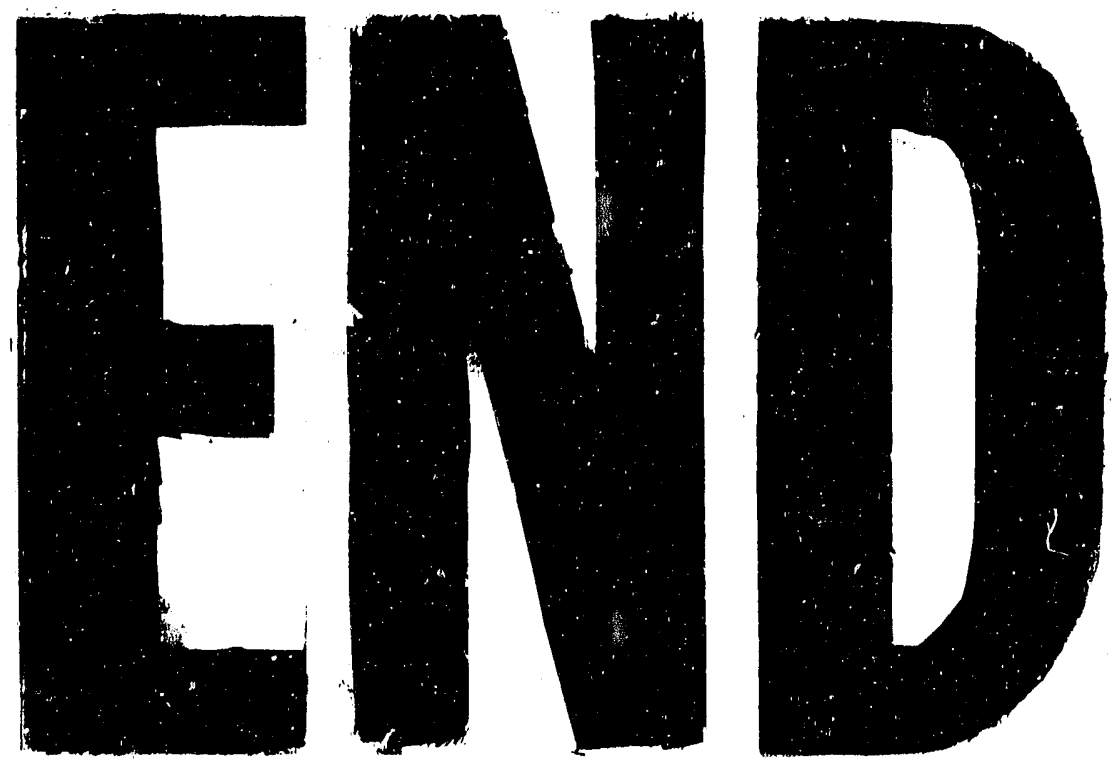

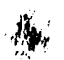
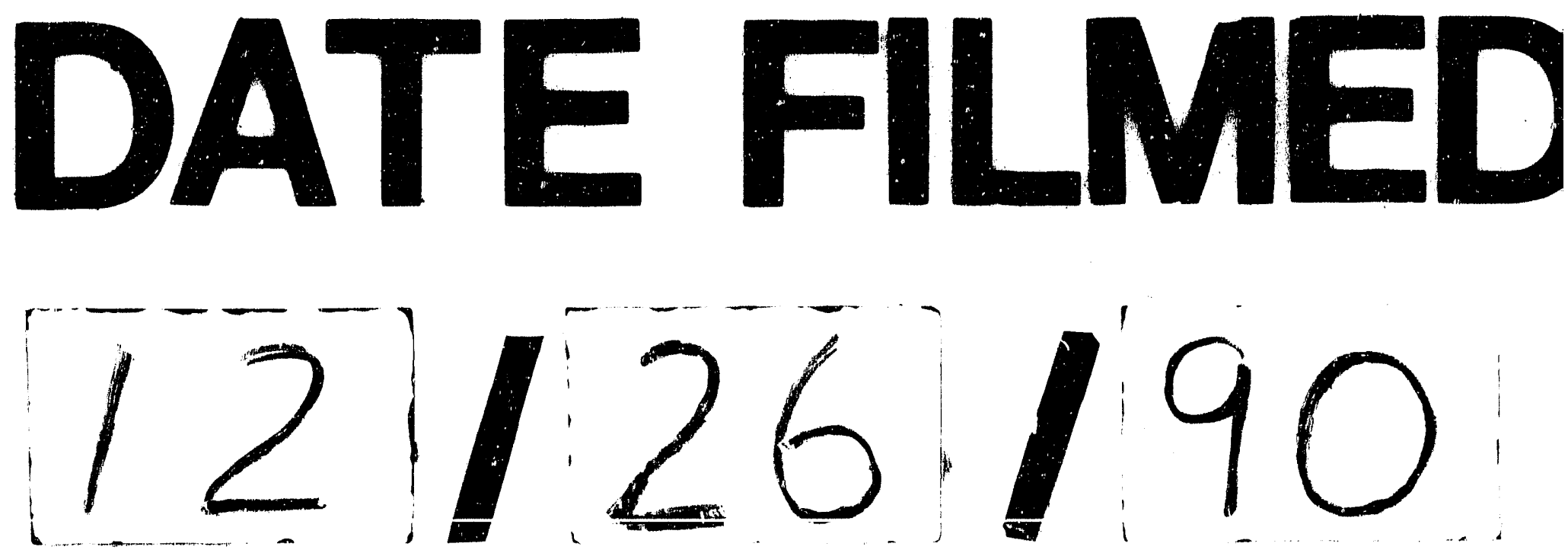


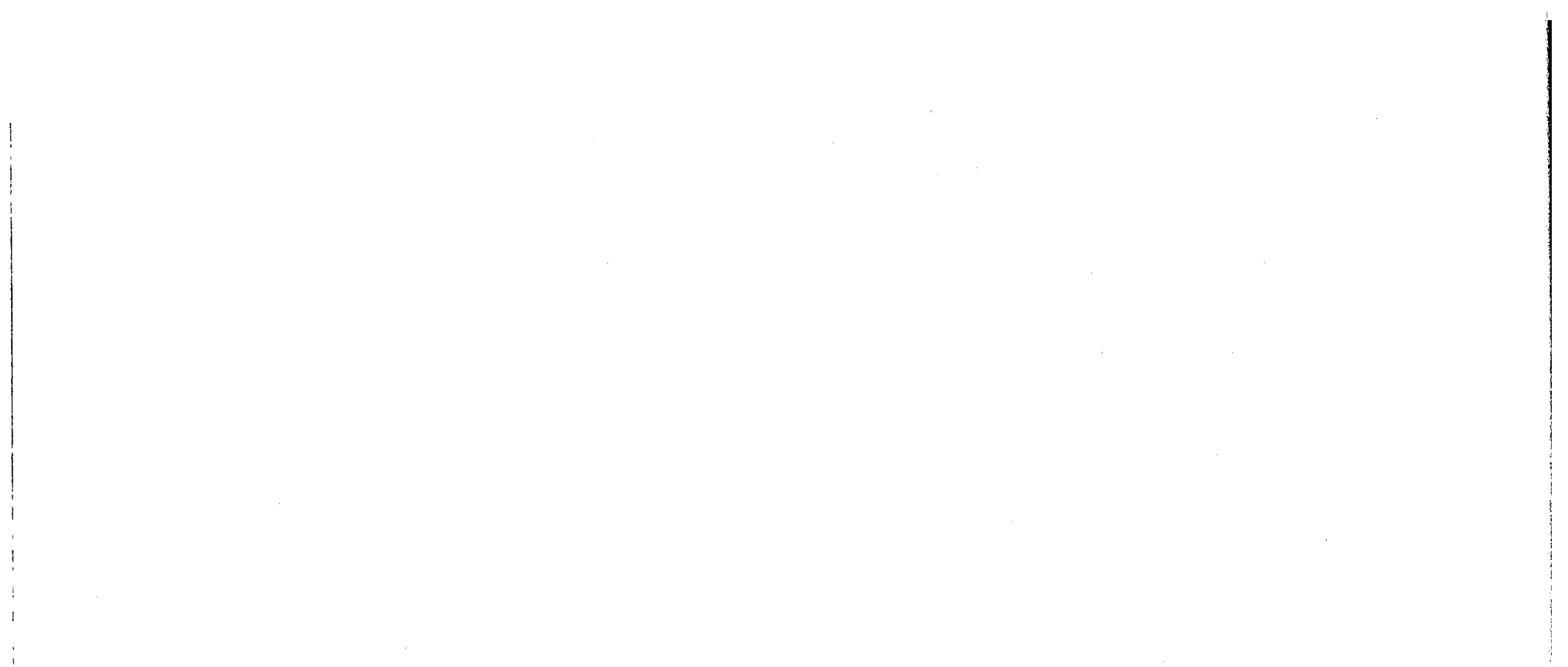

